\title{
A review on emerging micropollutants: sources, environmental concentration and toxicity
}

Vadiraj K.T. ${ }^{1}$, Raghu Ram Achar ${ }^{2 *}$ and Sindhuja Sirigeri ${ }^{3}$

DOI. 10.21931/RB/2021.06.04.29

\begin{abstract}
Every minute, the environment is filled with pollutants of various types, including physical, chemical, and biological. A new threat has emerged in recent years due to human activity, which is of significant concern. These pollutants are not like conventional pollutants but can alter the physiology of living things, and hence these are named emerging pollutants. The pollutant sources include crop protection chemicals, personal care products, antimicrobial mixtures, active pharmaceutical ingredients (API). These compounds are biologically crucial because their minute quantity can also disrupt an individual's endocrine system, and hence they are also called endocrine disruptors. This current work reviews many aspects, including source, problems, and legislative solutions that have been farmed to cope with the current situation of emerging micropollutants.
\end{abstract}

Key words: Emerging pollutants; chemicals, Active pharmaceutical ingredients (API), endocrine disruptors, microplastics.

\section{Introduction}

Micropollutants are chemical compounds usually found in lower concentrations in the aquatic environment ${ }^{1,2}$. Their amount in water may be significantly from undetectable to a few nanograms per liter ${ }^{3}$. The term micropollutants (M.P.s) are those, which were previously not considered nor had no significance in the quality of both ground and surface water by distribution and concentration ${ }^{4}$. These compounds were previously not available but are found widely in the recent past and can cause known or suspected adverse effects on human health and ecology. These compounds include natural and synthetic, such as pharmaceuticals and personal care products (PCPs), detergent, steroids, hormones, industrial compounds, pesticides, nanoparticles, and many other contaminants, increasing the environmental concern ${ }^{5-16}$. Bacteria with Antibiotic-resistant genes are also considered as emerging pollutants ${ }^{17}$.

Micro pollutants are called 'emerging' because they were not considered and were not included in monitoring programs as their fate, eco-toxicological behaviors are unknown ${ }^{18}$. However, it is a challenge to understand EMPs as less information is available. These EMPs started to be detected after the development of sophisticated chromatographic and mass spectrometric techniques ${ }^{19}$ at the traces levels, which led to large numbers of research to identify, quantify and catalog the EMPs by publishing them ${ }^{20-24}$.

\section{EMP regulation in various countries}

There is a large gap of scientific data relevant to the impacts and fates of EMPs with different concentrations. This has become a hurdle to various Governments around the world to control their usage and handling. It is a matter of more significant concern to handle the EMPs which have already entered the aquatic ecosystem. Specific laws concerning EMPs have not been framed globally, which would mandate concentration limits in any water source treatment plants or nature. The USA prepared an archive of observation techniques to handle enzyme-disrupting compounds and reduce their contact with human or animal life. This document did not have any permissible limits of these compounds in the water but reduced the concentration in consumer products ${ }^{25}$. The European commis- sion in 2000 framed a water framework Directive to achieve the good qualitative and quantitative status of all water bodies in the European Union (E.U. $)^{26}$. In 2013, it released a directive to list 45 priority compounds for their quality in the aquatic environment. In 2015, it added 10 more compounds to the watch list to assess the water quality ${ }^{26}$.

The E.U. set the permissible limit from 10 ppm and 10mg/ $\mathrm{kg}$ in surface water and soil to pharmaceutical drugs in the drinking water. In 1998 USFDA gave detailed protocols to assess human drugs, which led to the preparation of an environmental report on each compound and restricted their expected introduction to aquatic environments to $1 \mathrm{ppb}^{27}$. Switzerland proposed a similar mechanism to European Union's Environmental Quality standards (EQS) for water quality criteria for pharmaceutical compounds and pesticides ${ }^{28}$. These regulatory bodies of E.U. \& USA have tabulated the disinfection byproducts transformed from EMPs and published for general awareness ${ }^{29}$. But India has no such mechanisms to identify or regulate $\mathrm{EMPS}^{30}$.

In the case of pesticides, every country has its pesticide regulations regarding production, distribution, and utilization. In most countries, their occurrence in drinking water is not regulated through laws even though there are risks to human life and ecology 31,32 . In the case of India, these are considered as pollutants under the Water (Prevention \& Control of Pollution) Act 1974 , but their transformed byproducts are not included as pollutants. European Union in 1998 specified the maximum permissible limit of pesticide \& their byproduct in water is $1 \mathrm{ppb}$ and $0.5 \mathrm{ppb}$, respectively ${ }^{33}$. No specified pesticide was mentioned in this directive but created a monitoring authority to determine the pesticides present in drinking water. This led to identifying several pesticide risk indicators and developing various methodologies with different parameters, including the toxicity of aquatic organisms, assessment of health risks to humans on contact both by occupational exposure and by contaminated water or food ${ }^{34-38}$.

The Environmental Protection Agency (EPA) is an independent body in the USA that takes care of air, water, and soil problems. This agency has evolved over a century along with 
regulations related to the environment. EPA started to look into the adversity of M.P.s in 1985 by preparing detailed guidelines for national water and protecting aquatic life ${ }^{38,39}$.

Various researches showed the endocrine-disrupting activities by EMPs; EPA published a White paper in 2008. This includes the effect of chemicals on aquatic life during various stages of growth, toxicity, and specific mode of action. This white paper on aquatic life criteria for emerging contaminants was developed to modify the 1985 guidelines ${ }^{40,41}$.

Japan is a developed country with many water pollution episodes, such as mercury poisoning, cadmium poisoning, organic pollutants in ports, and nuclear pollution. But it has managed to overcome these problems by well-planned regulations and stringent action ${ }^{42}$. The umbrella act, Basic law of environmental pollution control, was enacted in 1967, which concerned human health, control of pollution, and conservation of natural resources. In 1970, a water pollution control law was enacted to protect water resources and was amended in 1995. By mode of follow approach and tightened regulations have given fruitful results ${ }^{42,43}$.

In this work, we tried to identify some significant chemicals used in various fields, EMPs in the Indian case scenario. Our focus was on chemicals used for crop protection, pharmaceutical drugs and personal care products. Here we tried to quantify them based on their availability to the public and identified their derivatives. In most cases, chemical derivatives were not identified not because of their ability to degrade but because of their insignificant amount in the water sources.

\section{Sources and Movement of EMPs in Environment}

When Non-Pathogenic, hazardous material is exposed to humans can cause a significant health risk. This effect increases if these compounds enter into the aquatic source from which drinking water is obtained. In many cases, these EMPs have been seen in drinking water; hence, an attempt is made to identify the pathways. These EMPs all transported through the general model as

1. Source: Agricultural land or Industrial outlet effluent or Sewage sludge in open land.

2. Flow of EMPs: Through fractures of aquifers Run-off from Rain Water.

\section{The receiver: Crops or tap water for drinking}

Sources of EMPs include wastewater derived from domestic, industrial, hospital premises and waste disposal sites widespread with various openings to the aqueous sources like surface or ground water sediments including pesticides from the agricultural farm, horticultural gardens parks (Figure 1), golf course, urban infrastructure and transport systems, discharge from hospital and industrial waste water which contains various pharmaceutical and PCPs (Figure 2 and 3) 44-46. Other sources include sewage and industrial sludge application on land, treatment of animals and pets with pesticides and pharmaceuticals ${ }^{47}$.

Potential sources of E.P.s are Agricultural farms includes crop protection compounds like pesticides, pheromones, hormones sprayed to the crops to protect the harvest. These compounds are deposited on either leaves or soil, leached into groundwater during raining or watering the $\mathrm{crops}^{48}$. Thus, a large number of pesticides and their derivatives enter into groundwater or run-off.

Hospital and industrial waste disposal sites in urban areas are also considered as the sources of EMPs. Polychlorinated biphenyls (PCB), polyaromatic hydrocarbons, alkyl phenols, dioxins furans have been identified in waste water for a long time. Many studies are conducted on waste water treatment effluents, sewage septic tanks, and artificial recharge treated effluents. These waters possess EMPs, majorly pharmaceutical from human excreta and unused pharmaceutical products, rare earth minerals, heavy metals, and contrast Medias ${ }^{49-54}$

In many parts of Asia, Europe, and the USA, animals are fed with a concentrated antibiotic diet, an essential source of environmental contamination with EMPs. These antibiotics are seen in waste lagoons, groundwater below lagoons, surface water such as ponds and rivers where this livestock is pastured, and the areas where animal waste is applied to fields as manure ${ }^{55-61}$.

In urban landfills have been a source of polluting ground water. The leachate from the landfill reaches ground water, including caffeine, nicotine, phenols, sterols, and phthalates ${ }^{61-63}$. Industrial pollutants are also found, such as detergents, antioxidants, plasticizers, fire retardants, and personal care products like antibiotics, anti-inflammatory, and barbiturates ${ }^{64}$

The path of EMPs in the transmission stage from source to receptors is always unclear. Various factors are involved during the transmission, such as aquatic environment, $\mathrm{pH}$, the solubility of compounds in water, biotic components in an aqueous ecosystem ${ }^{65,66}$. Considering these factors, the injection of EMPs to groundwater and surface water is studied. EMPs may enter through sewage leakages from septic tanks, wastewater application to agricultural fields, and leachate from landfills. These enter into ground water bypassing the soil zone ${ }^{67}$

In many cases, treated effluents from sewage and industries are discharged to surface water. The groundwater and surface water interaction is another method of transmission where the difference in density of waters leads to the exchange of compounds. Atmospheric transmission is also a possible case of nonvolatile dust compounds, especially in veterinary and agriculture ${ }^{68}$.

The end-user of water is humans for drinking and farming purposes. In the world, $11 \%$ of the population does not have a water supply, and $25 \%$ do not have proper sanitation facilities ${ }^{69}$. Hence every government agency utilizes the water available in the area without looking at the quality. Household connectivity of water and public standpipe bore well facilities are provided to improve the drinking water problem and sanitation. Hence the risk of exposure to pollutants is very high. So to reduce the risk, the drinking water treatment is carried out, but the effectiveness of the treatment is significantly less since the concentration is very less can escape from the detectors or indicators ${ }^{70}$

Wastewaters from animal shelters and agriculture are directly utilized for agriculture, where chemical compounds such as solvents, pesticides, and hormones are uptaken by crop plants and lead to poisoning. This issue has become a global concern as most food items are grown or processed in this water source and transmit the EMPs to far ends of the world ${ }^{71,72}$

Not just water and soil, even emerging pollutants in the air have gained attention recently. It is very well-acknowledged in recent reviews that study on micropollutants in the air is marginally studied.

It is known that the primary source of air pollution is the activities happening on soil and water through anthropogenic activities. Having said that, there exist natural sources of pollution such as dust and emissions from wildfires and volcanoes. In totality, particulate matter accompanied by volatile organic 


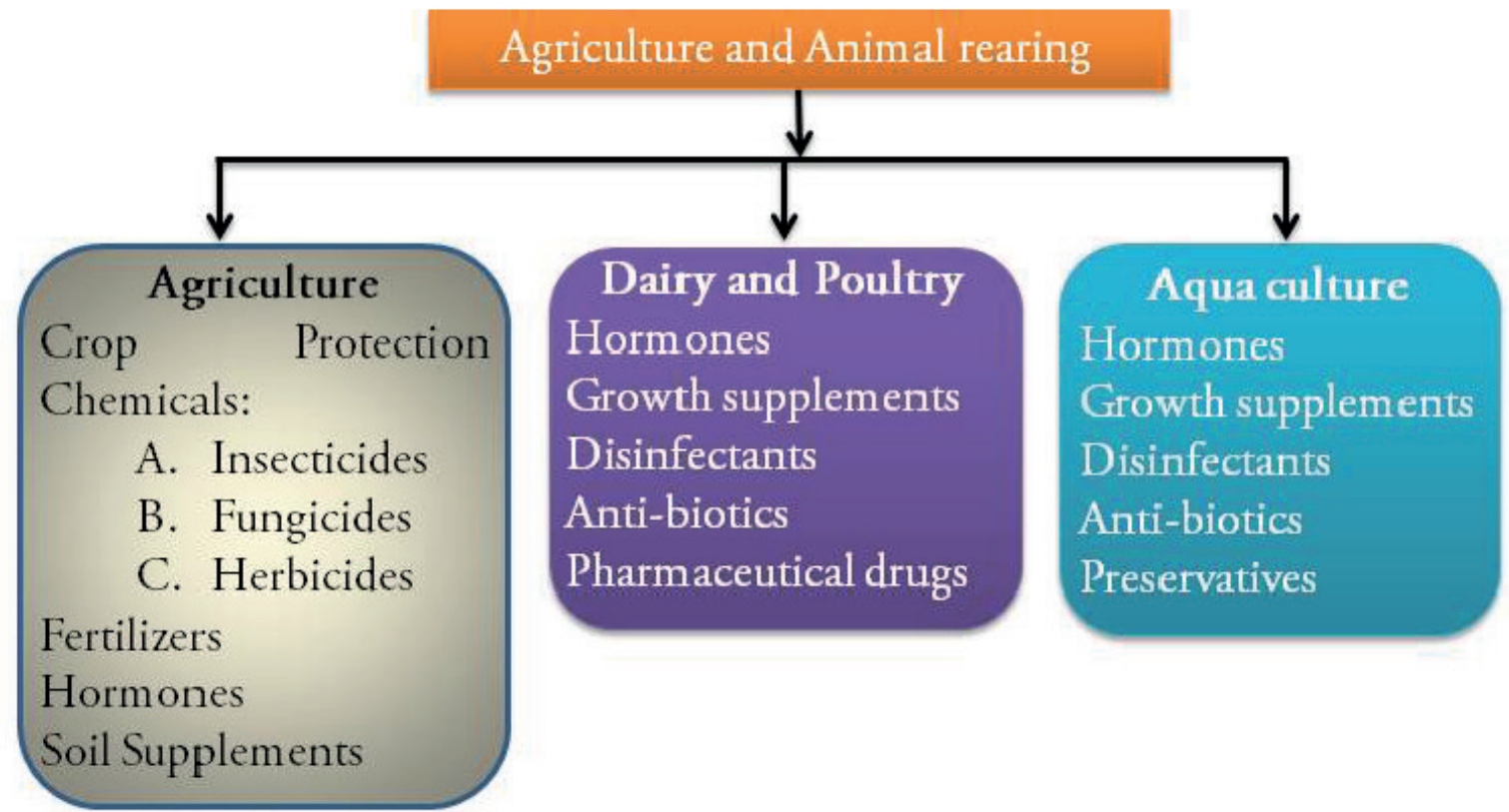

Figure 1. EMPs from Agricultural and allied Source.

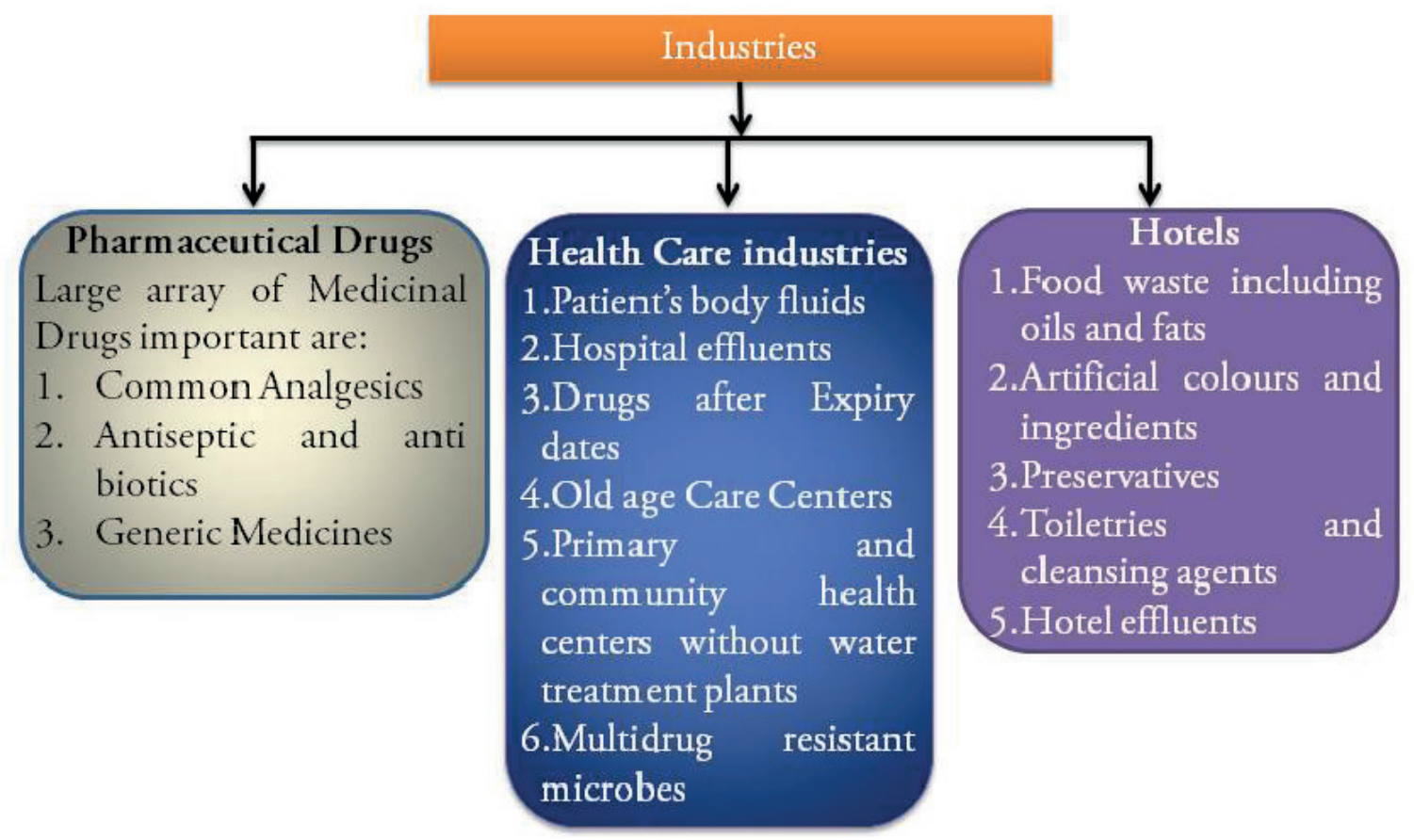

Figure 2. EMPs from various industrial sources.

compounds (VOCs), and other gases form the emerging pollutants in the air ${ }^{73}$

\section{Effects of EMPs on different organisms}

Hazardous materials are more toxic in lower concentrations and can cause acute and chronic disorders depending on the exposure. EMPs have nanoparticles, antibiotics, endocrine disrupting substances, pesticide derivatives, and hormones that can impact the organisms' daily activities and internal biology. The effects may be invisible in the initial stages, but continuous exposure can cause severe cellular imbalance. The list of EMPS and their adverse effects are tabulated in Table 1.

\section{Crop Protection chemicals}

Indian sub-continent has extended from equatorial to sub tropical regions $8^{\circ} \mathrm{N}$ to $38^{\circ} \mathrm{N}$ and spread through $70^{\circ} \mathrm{E}$ to $98^{\circ}$ E. It has compressed every ecosystem. Tropical Region is the primary structure of India, so the condition is favorable to grow the majority of crops and fruits. Hence, agriculture is the principal occupation that contributes 18\% to the GDP of the Indian economy. Approximately 58\% of the Indian population depends on agriculture for their daily livelihood. Export of cotton and production of sugar is expected to be increased by $9 \%$ and $23 \%$ by the end of 2018. India is the second-largest producer of fruits and the largest producer of spices globally ${ }^{85}$.

Crops are exposed to various pests, and to protect them from loss, hundreds of pesticides are produced and imported. Pesticides are of various types in the market depending upon the mode target-based and molecule-based. These are broadly classified into insecticides (Action on insects, mainly 


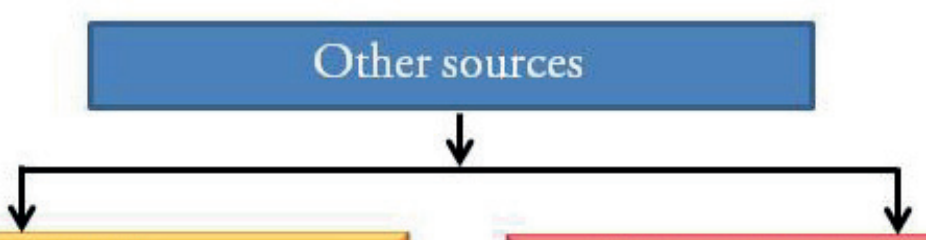

\section{Household}

1.Personal care products

2.Detergents

3.Artificial fumigant

4.Paints, colours, varnishes

5.Pharmaceutical drugs

6.Drugs (Expired)

7.Heavy metal and poly aromatic compounds (PHC) in daily appliances

Figure 3. EMPs present in sewage and other wastewaters

\section{Educational Institutions and laboratories}

1.Solvents

2. Nano Particles

3.Xenobiotic compounds

4.Polychlorinated compounds (PCCs)

5.Poly aromatic compounds (PAC)

6. Micro organisms (e.g: Bacterial cultures)

7.Disinfectants

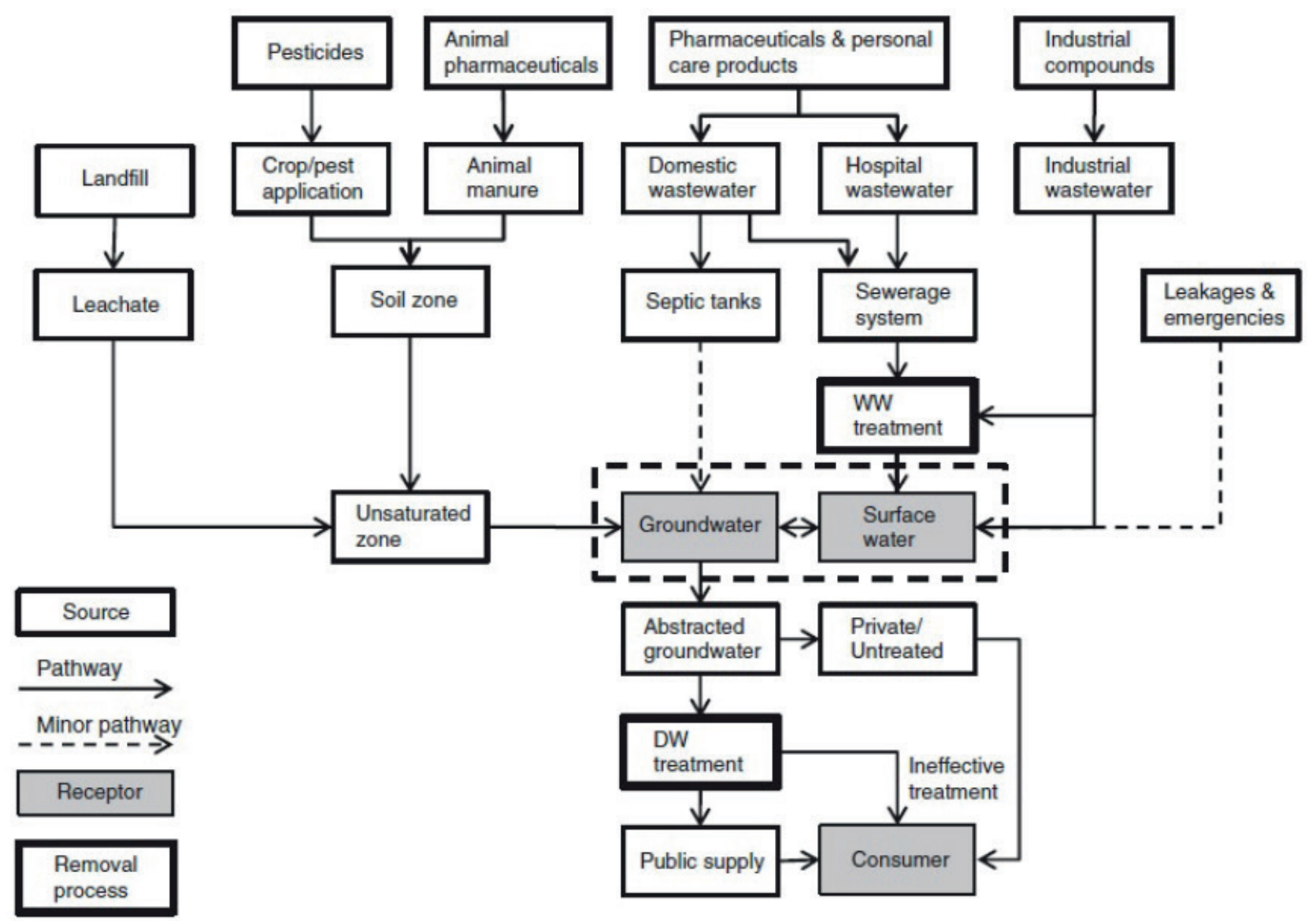

Figure 4. Expected pathway of EMPs from source to receiver. 


\begin{tabular}{|c|c|c|}
\hline Compounds & Adverse effects & References \\
\hline $\begin{array}{c}\text { Penicillin, sulfonamides, tetracyclines } \\
\text { (Antibiotics) }\end{array}$ & $\begin{array}{l}\text { Resistance among bacterial } \\
\text { pathogens that leading to } \\
\text { antibiotic-resistant strains, } \\
\text { reduction of efficiency of } \\
\text { treatment plants by reducing the } \\
\text { microbial number }\end{array}$ & 74,75 \\
\hline Caffeine (Stimulant) & $\begin{array}{l}\text { Endocrine disruption of goldfish } \\
\text { (Carassius auratus) }\end{array}$ & 76 \\
\hline $\begin{array}{l}\text { Diclofenac (Nonsteroidal anti- } \\
\text { inflammatory drug) }\end{array}$ & $\begin{array}{c}\text { Renal lesions and gill alterations } \\
\text { of rainbow trout (Oncorhynchus } \\
\text { mykiss) }\end{array}$ & 77 \\
\hline Triclocarban (Antimicrobial agents) & $\begin{array}{c}\text { Growth inhibition of algae } \\
\text { (Pseudokirchneriella subcapitata) }\end{array}$ & 78 \\
\hline $\begin{array}{l}\text { Bisphenol A (BPA) (Endocrine- } \\
\quad \text { disrupting compound) }\end{array}$ & $\begin{array}{c}\text { Show estrogenic effect and } \\
\text { hormonal disruption leads to } \\
\text { increase in risk of breast cancer in } \\
\text { humans }\end{array}$ & 79,80 \\
\hline $\begin{array}{l}\text { Estrone and } 17-\beta \text { estradiol (steroidal } \\
\text { estrogens) and } 17-\alpha \text { ethynylestradiol } \\
\text { (synthetic contraceptive) - contained in } \\
\text { contraceptive pills }\end{array}$ & $\begin{array}{l}\text { Causes change of sex in fishes } \\
\text { (feminization), mimics estrogen } \\
\text { hormone }\end{array}$ & 69,77 \\
\hline $\begin{array}{l}\text { Preservatives, i.e., parabens (alkyl-p } \\
\text { hydroxybenzoate) - used for anti- } \\
\text { microbiological preservatives in } \\
\text { cosmetics, toiletries, and even foods }\end{array}$ & Mimic Estrogenic Activity & 77,81 \\
\hline $\begin{array}{c}\text { Disinfectants/antiseptics,.i.e., (triclosan } \\
\text { - used in toothpaste, hand soaps, acne } \\
\text { cream) }\end{array}$ & $\begin{array}{l}\text { Reduction of the number of } \\
\text { microbial in treatment plants by } \\
\text { acting as biocides agent. }\end{array}$ & 82,83 \\
\hline Benzalkonium Chloride (Disinfectant) & $\begin{array}{l}\text { The observed increase in } \\
\text { antibiotic resistance }\end{array}$ & 84 \\
\hline
\end{tabular}

Table 1. List of EMPs and Adverse effects.

arthropods), fungicides (activity on the unwanted and harmful fungi species), and herbicides (action of unwanted herbs and bushes). Other categories include rodenticides (mammals like rats, mice, and bats) and bactericides. The pesticides used in India over the year 2012 have been shown in figure $5^{86}$.

\section{Pesticide usage pattern in India}

Currently, India supports $18 \%$ of the world population within $2.4 \%$ of the land and $4 \%$ of the water resources. India planned a green revolution to feed the enormous population and had successes. Indian Agriculture depends on Monsoon rains. Hence, the requirement to procure and maintain stock happens during pre-monsoon and post-monsoon seasons ${ }^{88}$. The requirements of pesticides are regularly checked during a zonal conference on the information of Karif and rabi by individual states. The Government of India will store these pesticide data to plan its agriculture policies for the next financial years. In the figure, 6 data of overall pesticides consumption and consumption per hectare are given from 1992-1993 to 20122013. The figure shows that the consumption of pesticides has declined from 72,130 tonnes to 56,090 tonnes. In 2015-2016 and 2016-2017, the consumption of pesticides was 53,719 and 56,215 tonnes, respectively. The consumption of pesticides has been fluctuating because of rainfall, pest infestation, and market availability. The main reason for the reduced use of pesticides is the awareness given by the states for their hazardous nature, and the importance of organic farming has yielded favorable results. And the development of new generation products that have shown to be highly effective at lower quantities is also a reason for the lower use of pesticides ${ }^{87-89}$.

Though the loss of crops due to pest attacks is high in India that is $15-25 \%$ of the produced is lost, the intensity of pesticides consumption is significantly less than $600 \mathrm{~g} / \mathrm{ha}$. This number has varied through the years. It has not crossed $1 \mathrm{~kg} /$ ha. This fluctuation from the year 1992-1993 to 2012-2013 has been shown in the figure. The other countries with high intensity of pesticides consumption are China (14 kg/ha), Japan (11 kg/ha), and the USA ( $4.5 \mathrm{~kg} / \mathrm{ha})$, and the world average is $3 \mathrm{~kg} / \mathrm{ha}$. Indian share of pesticides is about $3 \%$ of overall production, used for 16.4 million hectares under cultivation ( $9 \%$ of the total land) ${ }^{86}$.

\section{State-wise use of Pesticides}

The variations of pesticides consumption in different sta- 


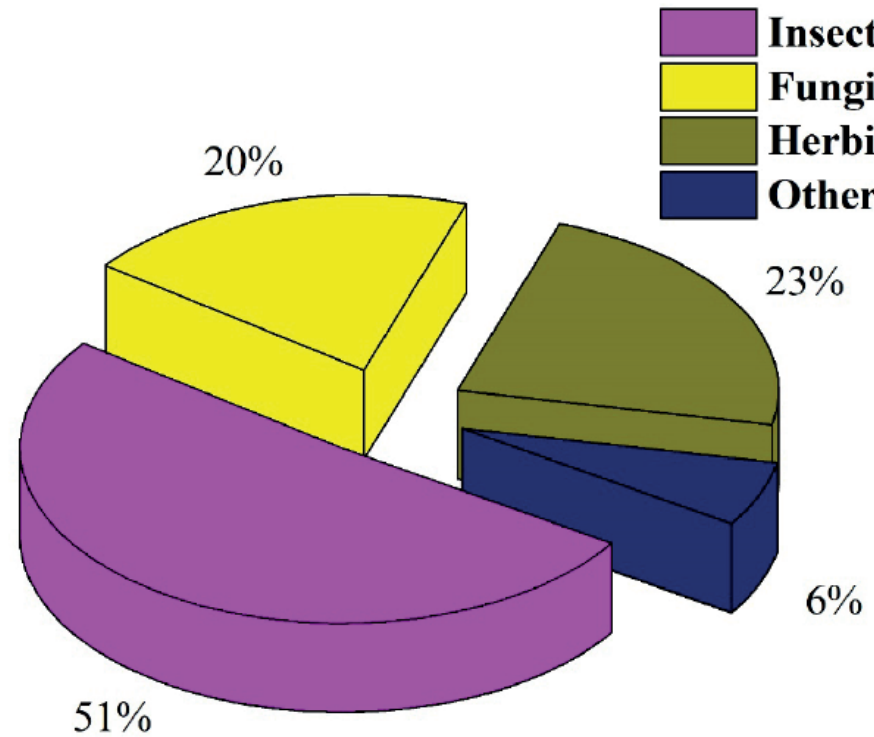

Figure 5. Overall Share of Pesticides Consumed in $2012^{87}$.

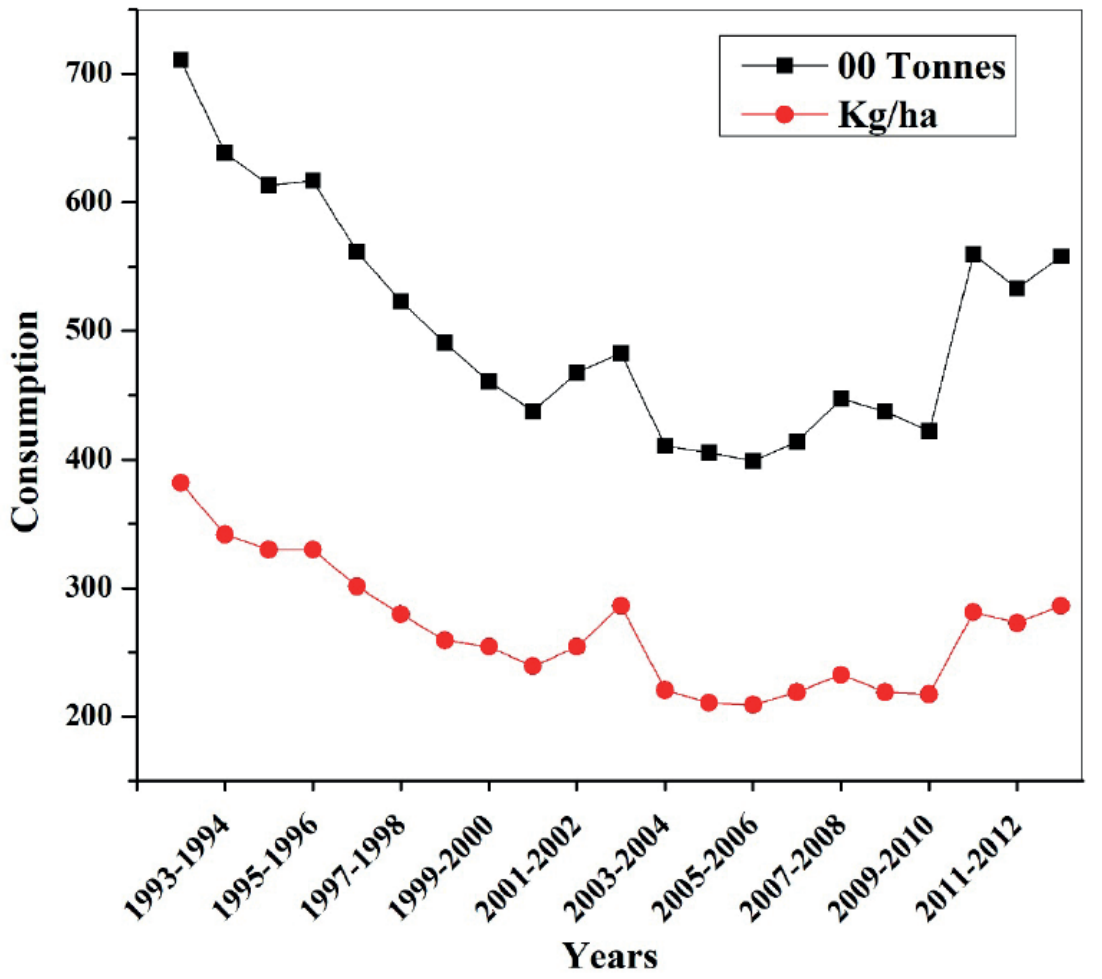

Figure 6. Consumption of pesticides in India (Black overall consumption and red the intensity of consumption) $)^{87,90 .}$

tes are shown in figure 7. Maharashtra, Uttar Pradesh, and Punjab are consuming higher pesticides with 13,500 tonnes, 10,200 tonnes, and 5,842 tonnes, respectively. These areas of Uttar Pradesh, Punjab, Haryana are in the plain of perennial rivers; hence annual crops are grown in turn requiring pesticides year long. Maharashtra is a state of cash crops and horticultural crops which require pesticides regularly. The states of South India utilize fewer pesticides due to organic farming that have been popularized in these states. In Kerala and a few parts of Karnataka, the victims of endosulfan pesticides are residing. Assam is the only state using many pesticides where Paddy is grown ${ }^{90}$. Both acute and chronic poisoning of endosulfans in humans is reported extensively. The reports majorly suggest the toxicity and harmful effects of endosulfans in Kasargod.

\section{Crops and pesticides}

The agricultural field has many single species of crops (Monoculture), increasing the chances of damage. Cash Crops are fruits, vegetables, cotton, plantation crops like coffee, tea, ginger etc., where a significant amount of crop protection chemicals are used. India is a tropical country and is exposed to a vivid type of climate which facilitates the parasites to easily infect and transmit to the whole crop field in no time. Thus, large numbers of these chemicals are put to the field where a part controls the pest, but the remaining part is leached out 
to soil or water. In figure 8 , the number of pesticides used in various crops is mentioned. About $50 \%$ of the pesticides are used on cotton because on every 15-day cycle; the pesticides are applied to kill and control large numbers of pests such as American bollworm, tobacco caterpillar, jassids etc. About $18 \%$ of crop protection chemicals are used on paddy fields. Paddy fields are exposed to insects such as plant hopper, rice bug, stem borer, fungal infections such as root and stem rots etc., and other pests include snails and birds mice, which are potent in reducing the production of crops.

Following paddy, crops of fruit and vegetables are primarily exposed to pests. In the preliminary stages, they include bacterial and fungal infections. During the fruiting season, insects, rodents, and mammals such as squirrels and bats attack the plantation. These are also exposed to a variety of weeds since these plantations are spaciously cultivated. Thus large quantities of chemical compounds are sprayed to the plantations to overcome this menace.

Following them, plantation crops (8\%) and cereals and millets $(7 \%)$ stand in the line. These plantation crops like coffee and tea are cultivated in elevated areas where rainfall is high, and the cereals and millets are cultivated in a dry land with less water availability where both the conditions will increase the risk of pest infestation; chemical compounds are used ${ }^{90}$.

\section{Top pesticides produced in India}

In the table above, 3, Insecticides, fungicides, and herbici- des produced are listed. Since India is a tropical country, most of the crops are infested with arthropods. Therefore, insecticides are majorly produced in the country compared to herbicides and fungicides. Organo-Phosphate pesticides are increasing in number because they are effective. Their residence time is 6-8 months. This gives the farmer an interval between two sprays.

\section{Top pesticides used in India}

Since India is a tropical country, most of the crops are infested with arthropods. Therefore, insecticides are majorly produced in the country compared to herbicides and fungicides. Previously Organo-chlorides dominated the pesticide field due to their effectiveness and persistence for longer durations. These were banned after various researches showed the cause of cancer and other endocrine disruption activity. Recently organo-Phosphate pesticides are being replaced, and residence time is hardly 6 months. This gives the farmer an interval between two sprays. In figure 9, major insecticides, fungicides, and herbicides produced in India in 2016 are given.

\section{Comparison of Pesticide Regulation in India with the developed country}

According to the Insecticide act 1968, more Chemical formulations and 110 combinations of crop protection chemicals have been registered. This act looked into the registration, manufacture, and distribution of pesticides ${ }^{92}$. Under this act, Central Insecticide Board and Registration Authority (CIBRA)

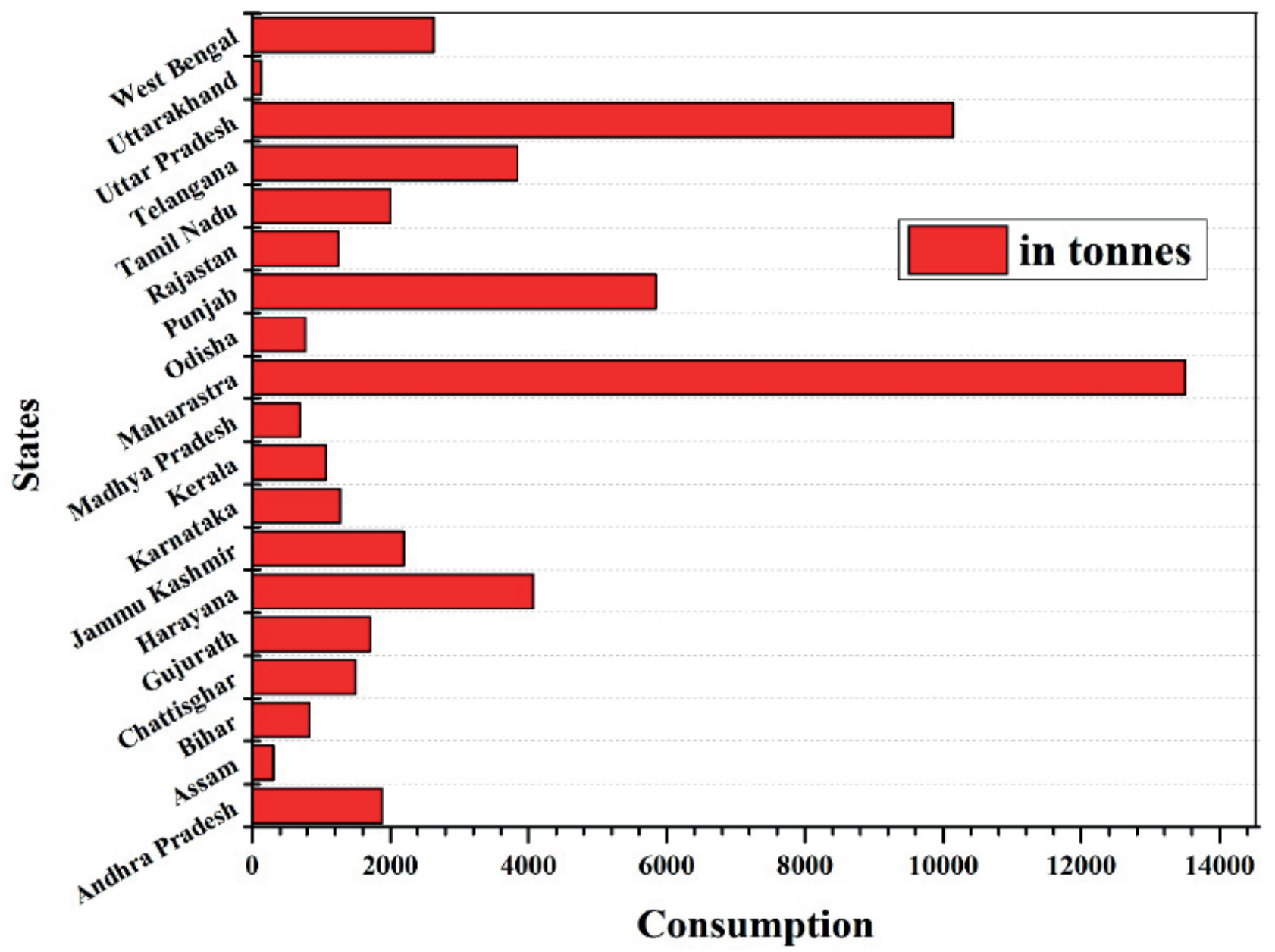

Figure 7. State-wise consumption of pesticides in the year 2016-1788,91 


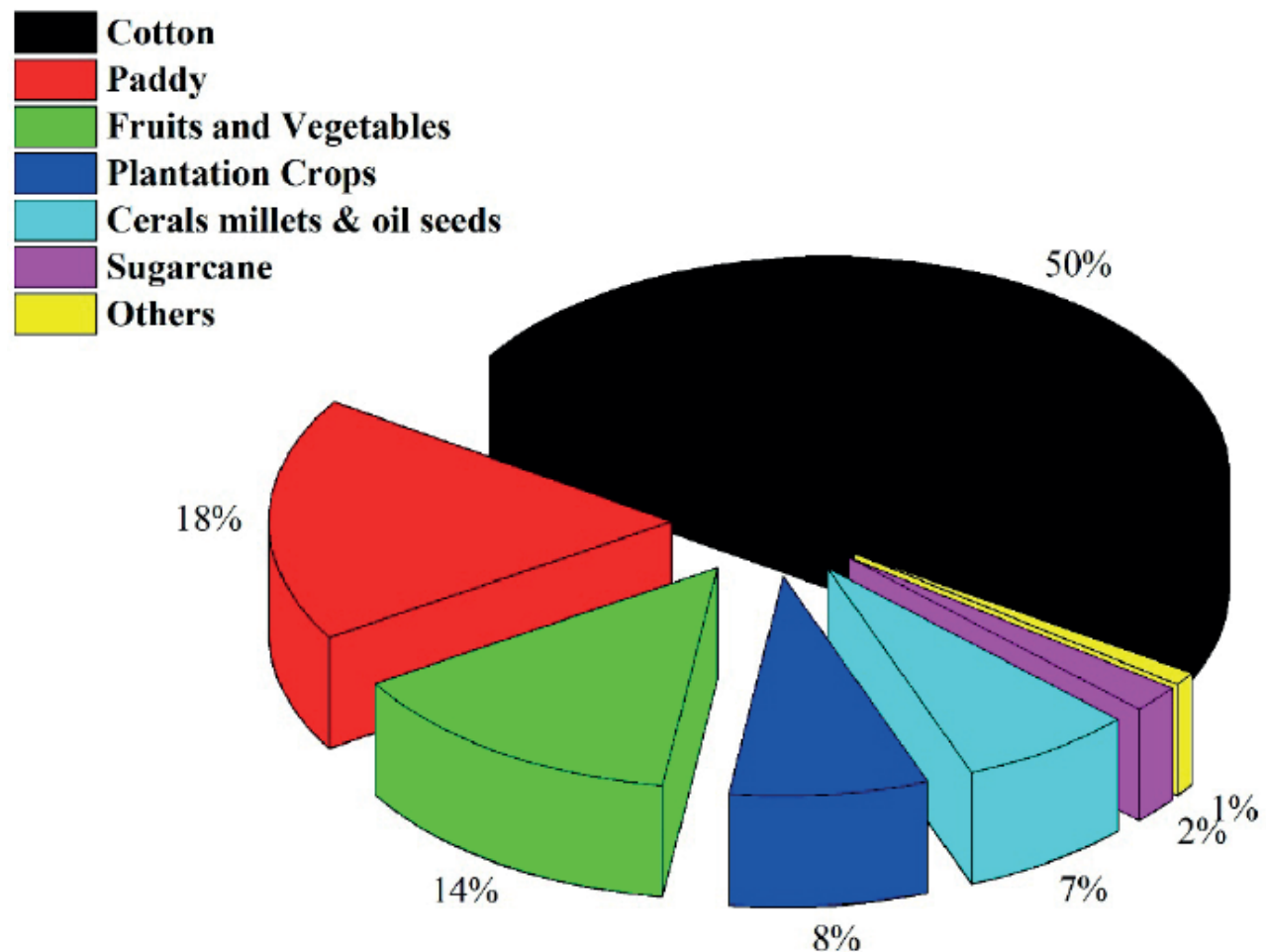

Figure 8. Percentage of Pesticides used on different $\mathrm{crops}^{86}$.

\begin{tabular}{|c|c|c|c|c|}
\hline $\begin{array}{c}\text { Crop } \\
\text { Protection } \\
\text { Chemicals }\end{array}$ & Type & $\begin{array}{l}\text { Mode of } \\
\text { Action }\end{array}$ & $\begin{array}{l}\text { Volume of } \\
\text { Production } \\
\text { (in Metric } \\
\text { tons) }\end{array}$ & Residues Expected \\
\hline Cartap & Carbamate & \multirow[t]{3}{*}{ Insecticide } & 50000 & $\begin{array}{l}\text { 4-(N,N-dimethylamino)- } \\
\text { 1,2-dithiolane }\end{array}$ \\
\hline Acephate & $\begin{array}{l}\text { Organo- } \\
\text { phosphate }\end{array}$ & & 20000 & Methamidophos \\
\hline Chlorpyriphos & $\begin{array}{l}\text { Organo- } \\
\text { phosphate }\end{array}$ & & 10000 & $\begin{array}{l}\text { 3,5,6-Trichloro-2- } \\
\text { Pyridinol }\end{array}$ \\
\hline Clodinofop & $\begin{array}{l}\text { pyridyl phenyl } \\
\text { ethers }\end{array}$ & \multirow[t]{3}{*}{ Herbicide } & 10000 & Persistent \\
\hline Glyphosate & $\begin{array}{l}\text { Organo- } \\
\text { phosphate }\end{array}$ & & 8000 & $\begin{array}{l}\text { Aminomethylphosphonic } \\
\text { acid }\end{array}$ \\
\hline Pretilachlor & Chloroactamide & & 5000 & $\begin{array}{l}\text { 2-chloro-N-(2,6- } \\
\text { dimethylphenyl)- } \\
\text { acetamide }\end{array}$ \\
\hline Mancozeb & Dithiocarbamate & \multirow[t]{2}{*}{ Fungicide } & 6000 & Ethylenethiourea (ETU) \\
\hline $\begin{array}{l}\text { Copper } \\
\text { Oxychloride }\end{array}$ & Metallic & & 4000 & copper oxalate \\
\hline Hexaconazole & - & & 4000 & $\begin{array}{l}\text { 1,2,4-Triazole, } 1 \mathrm{H}-1,2,4- \\
\text { Triazol-1-yl acetic acid }\end{array}$ \\
\hline
\end{tabular}

Table 2. Top 3 insecticides, herbicides, and fungicides produced in India along with the ir residual derivatives in water ${ }^{86,90,91 .}$ 


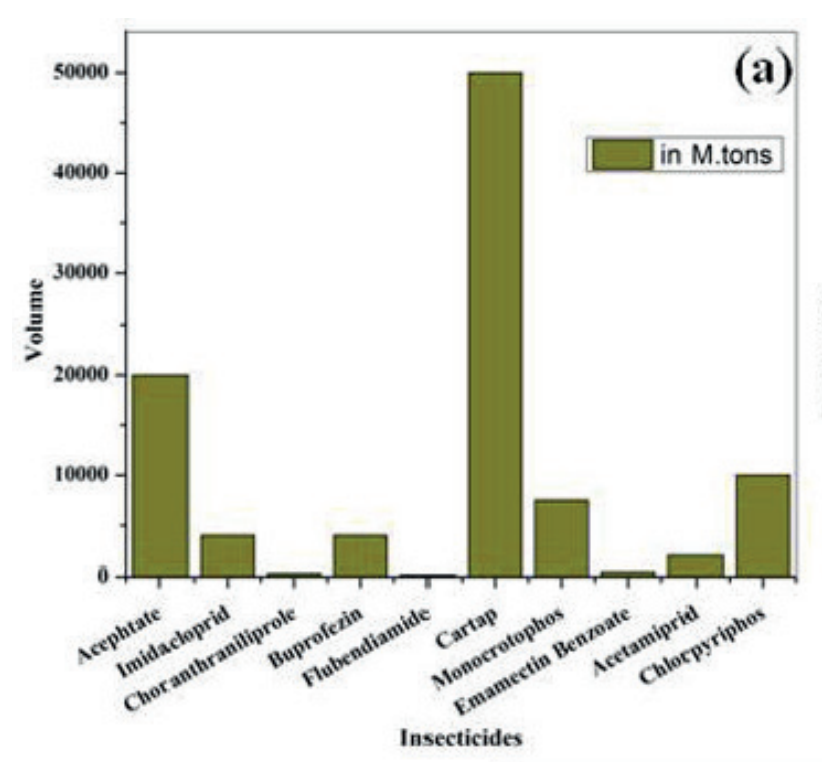

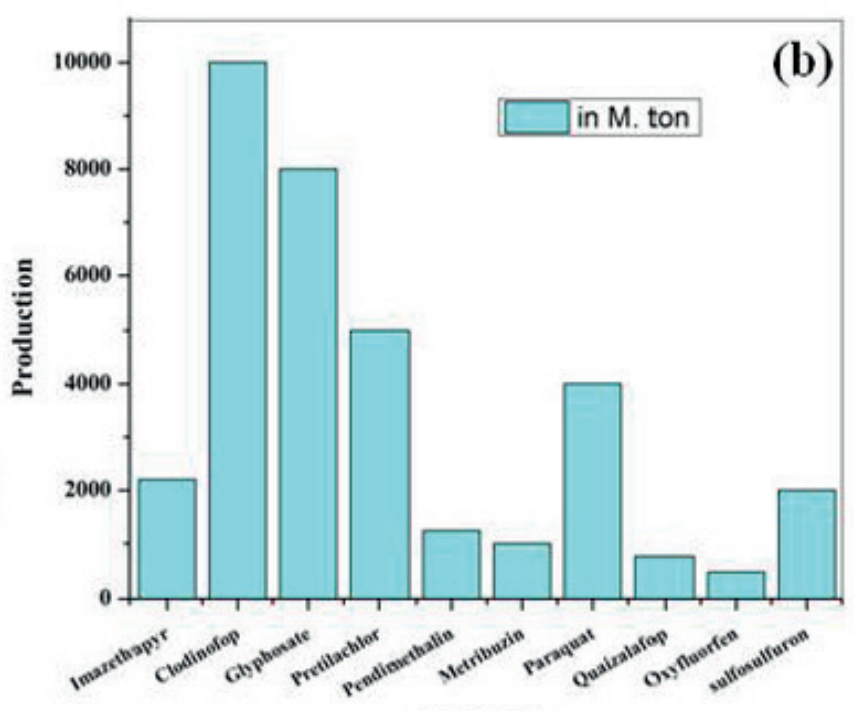

Herbicides

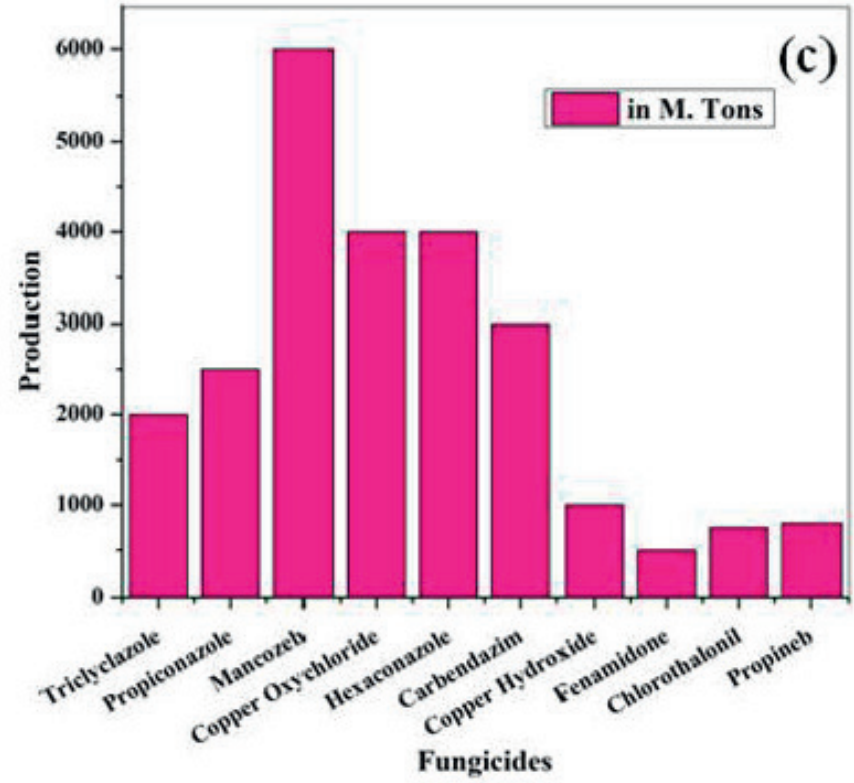

Figure 9. Different pesticides produced in India in 2016 (a. Insecticide, b. Herbicide, c. fungicide).

was set up, which carried out pesticide registration, evaluation related to the product chemistry, bio-efficacy, and toxicity. This regulatory body has banned 70 pesticides from importing and exporting or manufacturing in India ${ }^{93,94}$.

In 2006, the Food Safety and Security Authority of India (FSSAI) was formed under Food Safety and Security Act to look into the quality of food material. Under this act maximum, residual limits of pesticides were set. To strengthen the law on insecticide, in 2008, a new regulation pesticide management bill was introduced to limit tolerance limits to pesticides according to the Food Safety and Security Act ${ }^{89,95,96}$.

\section{European Union}

European Union has been straightening regulations regarding pesticides and plant protection chemicals. They have been evolving over the years with the current thematic strategy for pesticides. The European Union's health and Consumer Protection Directorate-General (under European Commission) is the regulatory body responsible for looking after the matter related to food health, pesticides and the member states authorize the use or ban of the products in their territories.
The lowest analytical permissible value of pesticides is set to $0.01 \mathrm{mg} / \mathrm{kg}$. The E.U. rules do not specify the pesticide or the crop in which they are used. A detailed protocol for sampling and determination of pesticide residue concerning maximum residual level is Gina in SANCO/12571/201389,97,98.

\section{USA}

In the USA, the United States Environmental Protection Agency is in-charge of pesticide registration and regulation. USEPA establishes the permissible risk limits of pesticide exposure, both occasional and occupation and child health on exposure. In most cases, tolerance exemptions are not allowed and are maintained consistently. Other Agency U.S. Department of Agriculture handles the pesticide detection in Agricultural products, meat, and poultry eggs. USFDA takes care of food material produced and imported into the country where it checks for the detection of pesticide and restricts the product to enter ${ }^{97,99-103}$.

\section{Japan}

Japan is the largest consumer of pesticides in the world. 
The regulatory body is the Ministry of Health, Labors, and Welfare. Japanese laws were general on food safety regarding poisonous and determined substances and did not specify any pesticides. In 2003, the pesticide limit was approved with a positive list. Under food sanitation law in 2006, maximum residue limits of pesticides were set under a positive list system. After the implementation, all agricultural products and imported products had to follow the procedures as per the positive list system. The highest tolerance limit was set to 0.01 ppm 42,43,104,105.

\section{Pesticides found in Indian Waters}

At the source, near the agricultural field, their concentration is very high. When the water enters the stream, these compounds dilute, thus reducing the chance of detection, which cannot be treatable. These untreatable, untraceable species cause emerging pollution in drinking water. In Tables 3 and 4 , a list of pesticides found in groundwater and surface water in India is given.

\section{Pharmaceutical drugs}

Pharmaceutical drugs are the compounds used as medicines in the cure of illness. These come in various types and forms, such as tablets, syrups, injection solutions, powder, inhalers. Illness may be to the man or animal; these are considered as lifesavers. These pharmaceuticals are used broadly and progressively are leading to ecological contamination. Broad-spectrum Antibiotics, legal and illicit drugs, analgesics, steroids, beta-blockers, and others are causing environmental issues ${ }^{107-110}$. Pharmaceutical pollutants are creating secondary pollutants called antibiotic-resistant microorganisms, which are also the reason for concern. The Active pharmaceutical ingredient (API) and their biotransformation are least studied, are the reason which nobody can anticipate their consequences to the ecosystem ${ }^{111-113}$. These compounds have entered the ecosystem in the past 100 years, but the study on their adverse effects started recently ${ }^{114}$.

Pharmaceutical drugs were not previously considered pollutants as they were entering the environment in lower concentrations; hence, they were considered pseudo pollutants. Over 160 pharmaceutical drugs are being detected in the water at lower concentrations of $\mathrm{ng} / \mathrm{L}$ to $\mathrm{ppm}$. Hence their eco-toxicological analysis and impact studies are inadequate to handle them ${ }^{112,115}$

In table 5 list of top 20 drugs prescribed in India which includes both generic and bulk drugs. In India, the highest prescribed drugs for lifestyle disease, specifically diabetes, then paracetamol, antibiotics, analgesics, and antiallergic drugs are followed by them ${ }^{116}$.

In the case of the USA, the condition is different. Paracetamol is a highly prescribed drug followed by Anti hypertension, antacids, antibiotics, and antidiabetics ${ }^{117}$. We could not find the number of drugs prescribed, but their revenue generated was identified.

\section{India and Pharmaceutical Industry}

Indian has a well-established pharmaceutical and healthcare industry. India is the third-largest pharmaceutical supplier, and about $40 \%$ of these drugs are generic. Pharmaceutical industries have been developed such that India supplies about $50 \%$ of global vaccines. India supplies $80 \%$ of the antiretroviral drugs used for combat acquired immune deficiency syndrome (AIDS).

The Healthcare industry is well spread in India with hospitals, telemedicine, medical tourism, health-related finance solutions. Both the Government and private health care delivery systems are operational. As of 2015 , more than 1.8 lakhs hospitals are operational in India, including government hospitals, private nursing homes, primary and community health care centers (PHCs and CHCs) 8,17,118,119.

Along with these credits, India is also the world's most significant consumer of Antibiotics. Carbapenem, a lifesaving antibiotic drug available, is sold on a large scale without prescription. Reports related to illicit prescription drugs are used for narcotics drugs leads to illegal production houses and dumping

EMPs generated by pharmaceutical industries and hospitals are detected in the Indian environmental samples at higher concentrations. Waters and sediments of Hyderabad have turned into poisons because of pharmaceutical wastes dumped into nearby water bodies and landfills ${ }^{120-124}$.

\section{Detection of Pharmaceutical drugs in various regions}

\section{Northern states}

Pharmaceutical drugs have been recorded in various water sources. The river Ganga (Haridwar, Kanpur, Allahabad), Yamuna, and at specific points of groundwater (Uttarakashi, Varanasi, Bhagamarg), wastewater (Kanpur, Ghaziabad, Delhi) STPs and secondary sludge (Delhi, Haridwar), sediment and drinking water (Gomathi river and Delhi), these EMPs were detected. Reports show that traces of drugs like caffeine, ibuprofen, paracetamol are found in River Ganga and Yamuna, along with higher concentrations of amoxicillin (Nondetectable levels to172.6 $\mathrm{ng} / \mathrm{L})$.

Antibiotics such as amoxicillin, Ciprofloxacin, gatifloxacin are detected in STP effluents in Delhi. Anti-inflammatory drugs like ibuprofen, diclofenac, antiepileptic drugs (carbamazepine), and other drugs were found in various samples at Ghaziabad and Lucknow in Uttar Pradesh. At SAS Nagar in Punjab, groundwater is contaminated with diclofenac ${ }^{125-131}$.

\section{Southern states in India}

These states are highly polluted with pharmaceutical wastes. The study starts at Patancheru near Hyderabad, turns out to be a point source of APIs. This area has a vast number of pharmaceutical manufacturing situated here made an important center for bulk drug production. High concentrations of APIs were found around the effluent treatment plant, of which 21 APIs are above 1ppm Ciprofloxacin, an antibiotic, was detected with the highest concentrations (31ppm), which is higher than the maximum therapeutic human plasma level. It was found even in sediment, surface, ground, and drinking water around $3 \mathrm{~km}$. The effluent is released into Musi River, and the concentration of Ciprofloxacin is $35.4-6058 \mu \mathrm{g} / \mathrm{L}$ in water and $11.4-4763.3 \mathrm{ng} / \mathrm{l}$ in sediments. Other than antibiotics, antifungal agents, fluconazole was found in the sewage of nearby areas. The famous Hussain Sagar Lake of Hyderabad has norfloxacin, and sulfamethoxazole was found $53,124,125,128,132-136$.

Other categories of pharmaceutical drugs are detected in South India, such as Udupi, Bangalore, Coimbatore, Chennai landfills. It is reported that $5.1 \mathrm{~kg}$ of caffeine and $2.1 \mathrm{~kg}$ ibuprofen are discharged annually to SIP in Udupi ${ }^{137-139}$.

\section{Eastern and western zones}

Few reports found in these regions, indicating gaps in pharmaceutical pollution research in these areas. Most illicit drugs and pharmaceuticals are found in the surface waters of Saidpur and Bener in Bihar. Ibuprofen and amphetamine were 


\begin{tabular}{|c|c|c|c|}
\hline Place & Pesticide & Pesticide detected & $\begin{array}{l}\text { Quantification } \\
\text { technique }\end{array}$ \\
\hline \multirow[t]{3}{*}{ Jaipur, Rajasthan } & $\begin{array}{l}\text { Heptachlor } \\
\text { epoxide, }\end{array}$ & $0.943 \mathrm{mg} / \mathrm{kg}$ & \multirow[t]{3}{*}{ GC-ECD } \\
\hline & Heptachlor, & $0.736 \mathrm{mg} / \mathrm{kg}$ & \\
\hline & Aldrin & $0.336 \mathrm{mg} / \mathrm{kg}$ & \\
\hline \multirow[t]{6}{*}{ Dug wells, Unnao, UP } & EAldrin & BDL-1355.2 ng/1 & \multirow[t]{6}{*}{ GC-ECD and GC-MS } \\
\hline & $\Sigma$ Chlordane & BDL-7.2 ng/1 & \\
\hline & $\Sigma$ Endosulfan & BDL- $54.4 \mathrm{ng} / \mathrm{l}$ & \\
\hline & $\Sigma \mathrm{DDT}$ & BDL-266 ng/1 & \\
\hline & $\Sigma \mathrm{HCH}$ & $0.56-2920.9 \mathrm{ng} / 1$ & \\
\hline & ¿Heptachlor & BDL-303.6 ng/1 & \\
\hline \multirow[t]{4}{*}{ Hyderabad, A.P. } & Lindane & $0.78-1.39 \mathrm{ppb}$ & \multirow[t]{4}{*}{ GC-ECD } \\
\hline & DDT & $0.15-0.19 \mathrm{ppb}$ & \\
\hline & $\alpha$ Endosulfan & $1.98-2.86 \mathrm{ppb}$ & \\
\hline & $\beta$ Endosulfan & $0.30-0.32 \mathrm{ppb}$ & \\
\hline \multirow[t]{5}{*}{ Hisur, Harayana } & $\Sigma \mathrm{HCH}$ & $0.41-2.31 \mathrm{ppb}$ & \multirow[t]{5}{*}{ GC ECD and NPD } \\
\hline & $\Sigma \mathrm{DDT}$ & $0.05-0.86 \mathrm{ppb}$ & \\
\hline & EEndosulfan & $0.02-0.37 \mathrm{ppb}$ & \\
\hline & Cypermethrin & $0.02-0.09 \mathrm{ppb}$ & \\
\hline & Deltamethrin & $0.17-0.06 \mathrm{ppb}$ & \\
\hline \multirow{2}{*}{$\begin{array}{l}\text { Sonapur Greater } \\
\text { Kolkata WB }\end{array}$} & Aldrin/dieldrin & $0.01-0.03 \mathrm{ppb}$ & \multirow[t]{2}{*}{ GLC } \\
\hline & Dicifol & $0.02-0.03 \mathrm{ppb}$ & \\
\hline \multirow[t]{5}{*}{ Nanded, Maharashtra } & Endosulfan & $1.50-4.00 \mathrm{ppb}$ & \multirow[t]{5}{*}{ GC-ECD } \\
\hline & Heptachlor & $0.00-0.03 \mathrm{ppb}$ & \\
\hline & Aldrin/dieldrin & $0.01-0.04 \mathrm{ppb}$ & \\
\hline & $\mathrm{HCB}$ & $1.00-2.00 \mathrm{ppb}$ & \\
\hline & DDT & $2.00-4.00 \mathrm{ppb}$ & \\
\hline \multirow{16}{*}{$\begin{array}{l}\text { Bore wells of Delhi } \\
\text { region, Delhi }\end{array}$} & $\alpha-\mathrm{HCH}$ & $0.003-0.005 \mathrm{ppb}$ & \multirow[t]{16}{*}{ GC ECD and GC MS } \\
\hline & $\beta-\mathrm{HCH}$ & $0.008-0.037 \mathrm{ppb}$ & \\
\hline & $\gamma-\mathrm{HCH}$ & $0.007-0.014 \mathrm{ppb}$ & \\
\hline & $\delta-\mathrm{HCH}$ & $0.013-0.039 \mathrm{ppb}$ & \\
\hline & Heptachlor & $0.028-0.032 \mathrm{ppb}$ & \\
\hline & Aldrin & $0.011-0.034 \mathrm{ppb}$ & \\
\hline & $\alpha$ Endosulfan & $0.034 \mathrm{ppb}$ & \\
\hline & $\begin{array}{l}\text { Heptachlor } \\
\text { epoxide, }\end{array}$ & $0.016-0.026 \mathrm{ppb}$ & \\
\hline & dieldrin & $0.009-0.058 \mathrm{ppb}$ & \\
\hline & $\mathrm{DDE}$ & $0.018-0.046 \mathrm{ppb}$ & \\
\hline & Endrin & $0.029-0.054 \mathrm{ppb}$ & \\
\hline & $\beta$ Endosulfan & $0.031-0.060 \mathrm{ppb}$ & \\
\hline & DDD & $0.024-0.055 \mathrm{ppb}$ & \\
\hline & Endosulfan Sulfate & $0.036-0.057 \mathrm{ppb}$ & \\
\hline & DDT & $0.068-0.093 \mathrm{ppb}$ & \\
\hline & Methoxychlor & $0.066-0.094 \mathrm{ppb}$ & \\
\hline
\end{tabular}

Table 3. Pesticide found in Ground water and their analytical techniques ${ }^{106}$. 


\begin{tabular}{|c|c|c|c|}
\hline Lake/River/ Place & Pesticides Detected & $\begin{array}{c}\text { Detected } \\
\text { concentration }\end{array}$ & Detection method \\
\hline Unnao, UP & Aldrin & BDL-1.88 ppb & GC ECD and GC MS \\
\hline \multirow{10}{*}{$\begin{array}{l}\text { Greater Kolkata, } \\
\text { W.B. }\end{array}$} & $\Sigma$ Chlordane & BDL-0.04 ppb & \\
\hline & $\Sigma \mathrm{DDT}$ & BDL-0.23 ppb & \\
\hline & $\Sigma \mathrm{HCH}$ & $1.88-1.95 \mathrm{ppb}$ & \\
\hline & $\Sigma$ Heptachlor & BDL-0.11 ppb & \\
\hline & Methoxychlor & $2.63-3.72 \mathrm{ppb}$ & \\
\hline & Lindane & $0.01-0.05 \mathrm{ppb}$ & \multirow[t]{5}{*}{ GLC } \\
\hline & $\mathrm{HCH}$ & $0.01-9.90 \mathrm{ppb}$ & \\
\hline & Aldrin/dieldrin & $0.01-0.90 \mathrm{ppb}$ & \\
\hline & Dicofol & $0.01-14.03 \mathrm{ppb}$ & \\
\hline & DDT & $0.01-1.40 \mathrm{ppb}$ & \\
\hline \multirow{3}{*}{$\begin{array}{c}\text { Baratagi lake, } \\
\text { Bijapur, Karnataka }\end{array}$} & Endosulfan & $0.00025 \mathrm{mg} / \mathrm{kg}$ & \multirow[t]{3}{*}{ GC ECD and GC MS } \\
\hline & Chlorpyrifos ethyl & $0.0002 \mathrm{mg} / \mathrm{kg}$ & \\
\hline & $\begin{array}{l}\text { 4-bromo-2- } \\
\text { chlorophenol }\end{array}$ & $0.0003 \mathrm{mg} / \mathrm{kg}$ & \\
\hline \multirow[t]{3}{*}{ Hisar, Haryana } & $\Sigma \mathrm{DDT}$ & $50.1-332.2 \mathrm{ng} / 1$ & \multirow[t]{3}{*}{ GC ECD } \\
\hline & $\Sigma \mathrm{HCH}$ & $2.3-560.6 \mathrm{ng} / 1$ & \\
\hline & $\Sigma$ Endosulfan & BDL-206.3 ng/1 & \\
\hline \multirow{2}{*}{$\begin{array}{l}\text { Khindsi lake, } \\
\text { Bhandara, } \\
\text { Maharashtra }\end{array}$} & $\alpha-\mathrm{HCH}$ & $0.019-0.120 \mathrm{ppb}$ & \multirow[t]{2}{*}{ GC ECD and GC MS } \\
\hline & $\beta-\mathrm{HCH}$ & $0.031-0.061 \mathrm{ppb}$ & \\
\hline \multirow{9}{*}{$\begin{array}{c}\text { Tamiraparani river } \\
\text { basin }(T N)\end{array}$} & $\Sigma \mathrm{HCH}$ & $0.01 \mathrm{ng} / 1$ & \multirow[t]{9}{*}{ GC MS } \\
\hline & $\Sigma \mathrm{DDT}$ & $0.01-0.72 \mathrm{ng} / 1$ & \\
\hline & Heptachlor & $0.06-2.1 \mathrm{ng} / \mathrm{l}$ & \\
\hline & Aldrin & $0.02-1.5 \mathrm{ng} / 1$ & \\
\hline & Trans-chlordane & $0.01 \mathrm{ng} / 1$ & \\
\hline & Cis-chlordane & $0.01 \mathrm{ng} / 1$ & \\
\hline & Dieldrin & $0.03-7.5 \mathrm{ng} / 1$ & \\
\hline & Endrin & $0.02-58.0 \mathrm{ng} / 1$ & \\
\hline & Mirex & $0.01-0.47 \mathrm{ng} / 1$ & \\
\hline \multirow{5}{*}{$\begin{array}{l}\text { Rishikesh, Ganga } \\
\text { river, Uttarakhand }\end{array}$} & $\sum \mathrm{HCH}$ & $5.54 \mathrm{ng} / 1$ & \multirow[t]{5}{*}{ GC ECD and GC MS } \\
\hline & $\Sigma \mathrm{DDT}$ & $1.01 \mathrm{ng} / 1$ & \\
\hline & $\Sigma$ Endosulfan & $0.92 \mathrm{ng} / 1$ & \\
\hline & EAldrin & $1.89 \mathrm{ng} / 1$ & \\
\hline & $\Sigma$ Heptachlor & $0.32 \mathrm{ng} / 1$ & \\
\hline \multirow{8}{*}{$\begin{array}{l}\text { Cauvery river, } \\
\text { Karnataka }\end{array}$} & $\alpha-\mathrm{HCH}$ & $0.87 \mathrm{ppb}$ & \multirow[t]{2}{*}{ GC ECD } \\
\hline & $\beta-\mathrm{HCH}$ & $0.56 \mathrm{ppb}$ & \\
\hline & $\gamma-\mathrm{HCH}$ & $0.93 \mathrm{ppb}$ & \\
\hline & $\delta-\mathrm{HCH}$ & $0.78 \mathrm{ppb}$ & \\
\hline & p.p’-DDT & $0.64 \mathrm{ppb}$ & \\
\hline & p. p'-DDE & $0.96 \mathrm{ppb}$ & \\
\hline & p. p'-DDD & $0.53 \mathrm{ppb}$ & \\
\hline & Endosulfan & $0.84 \mathrm{ppb}$ & \\
\hline
\end{tabular}




\begin{tabular}{|c|c|c|c|c|c|}
\hline Sl. No. & Brand Name & $\begin{array}{c}\text { Active } \\
\text { Pharmaceutical } \\
\text { Ingredient (API) }\end{array}$ & $\begin{array}{c}\text { Class of } \\
\text { Pharmaceuti } \\
\text { cal }\end{array}$ & Company & $\begin{array}{c}\text { Moving } \\
\text { Annual } \\
\text { Turnover (in } \\
\text { Rs. Cr) }\end{array}$ \\
\hline 1. & Mixtard & Soluble Insulin & $\begin{array}{c}\text { Anti- } \\
\text { Diabetic }\end{array}$ & $\begin{array}{l}\text { Novo } \\
\text { Nordisk, } \\
\text { India }\end{array}$ & 512 \\
\hline 2. & Glycomet & Metformin & $\begin{array}{c}\text { Anti- } \\
\text { Diabetic }\end{array}$ & USV & 415 \\
\hline 3. & $\begin{array}{l}\text { Spasmo } \\
\text { Proxyvon } \\
\text { Plus }\end{array}$ & $\begin{array}{l}\text { Dicyclomine, } \\
\text { Paracetamol, } \\
\text { Tramadol }\end{array}$ & $\begin{array}{l}\text { Anti- } \\
\text { Cholinergic } \\
\text { and } \\
\text { Analgesic }\end{array}$ & Wockhardt & 377 \\
\hline 4. & Lantus & Insulin glargine & $\begin{array}{c}\text { Anti- } \\
\text { Diabetic }\end{array}$ & $\begin{array}{l}\text { Sanofi } \\
\text { India }\end{array}$ & 341 \\
\hline 5. & Galvus & $\begin{array}{l}\text { Metformin- } \\
\text { Vildagliptin }\end{array}$ & $\begin{array}{c}\text { Anti- } \\
\text { Diabetic }\end{array}$ & $\begin{array}{l}\text { Novartis } \\
\text { India }\end{array}$ & 328 \\
\hline 6. & $\operatorname{Liv} 52$ & $\begin{array}{c}\text { Natural } \\
\text { Ingredients }\end{array}$ & $\begin{array}{l}\text { Hepato } \\
\text { Protective }\end{array}$ & $\begin{array}{l}\text { Himalayan } \\
\text { Grugs }\end{array}$ & 296 \\
\hline 7. & Janumet & $\begin{array}{l}\text { Sitagliptin, } \\
\text { Metformin }\end{array}$ & $\begin{array}{c}\text { Anti- } \\
\text { Diabetic }\end{array}$ & $\begin{array}{r}\text { MSD } \\
\text { Pharma }\end{array}$ & 285 \\
\hline 8. & Augmentin & $\begin{array}{l}\text { Amoxicillin, } \\
\text { Clavilanate } \\
\text { potassium }\end{array}$ & Anti-Biotics & GSK & 283 \\
\hline 9. & Clavam & $\begin{array}{l}\text { Amoxicillin, } \\
\text { Clavulanic Acid }\end{array}$ & Anti-Biotics & $\begin{array}{l}\text { Alkem } \\
\text { Labs }\end{array}$ & 281 \\
\hline 10. & Monocef & Ceftriaxone & Anti-Biotics & $\begin{array}{r}\text { Aristo } \\
\text { Pharma }\end{array}$ & 277 \\
\hline 11. & Voveran & Diclofenac & $\begin{array}{c}\text { Analgesic } \\
\text { and Anti- } \\
\text { inflammatory }\end{array}$ & $\begin{array}{l}\text { Novartis } \\
\text { India }\end{array}$ & 266 \\
\hline 12. & Novomix & $\begin{array}{l}\text { Protamine- } \\
\text { crystallised } \\
\text { Insulin }\end{array}$ & $\begin{array}{c}\text { Anti- } \\
\text { Diabetic }\end{array}$ & $\begin{array}{c}\text { Novo } \\
\text { Nordisk India }\end{array}$ & 263 \\
\hline 13. & Betadine & Povidone-iodine & Antiseptic & $\begin{array}{c}\text { Win } \\
\text { Medicare }\end{array}$ & 253 \\
\hline 14. & PAN & $\begin{array}{l}\text { Domperidone, } \\
\text { Pantoprazole } \\
\text { Sodium } \\
\text { Sesquihydrate }\end{array}$ & Anti-ulcer & Alkem Lab & 250 \\
\hline 15. & Volini & $\begin{array}{c}\text { Diclofenac } \\
\text { Diethylammoniu } \\
\text { m Topical, } \\
\text { Menthol Topical, } \\
\text { Methyl Salicylate } \\
\text { Topical, Oleum } \\
\text { Lini Topical }\end{array}$ & $\begin{array}{c}\text { Analgesic } \\
\text { and Anti- } \\
\text { inflammatory }\end{array}$ & Ranbaxy & 248 \\
\hline 16. & Synflorix & $\begin{array}{l}\text { Pneumococcal } \\
\text { Polysaccharide } \\
\text { Conjugate }\end{array}$ & Vaccines & GSK & 237 \\
\hline
\end{tabular}

Table 5. Top pharmaceutical drugs produced in India with APIs and category ${ }^{117}$. 


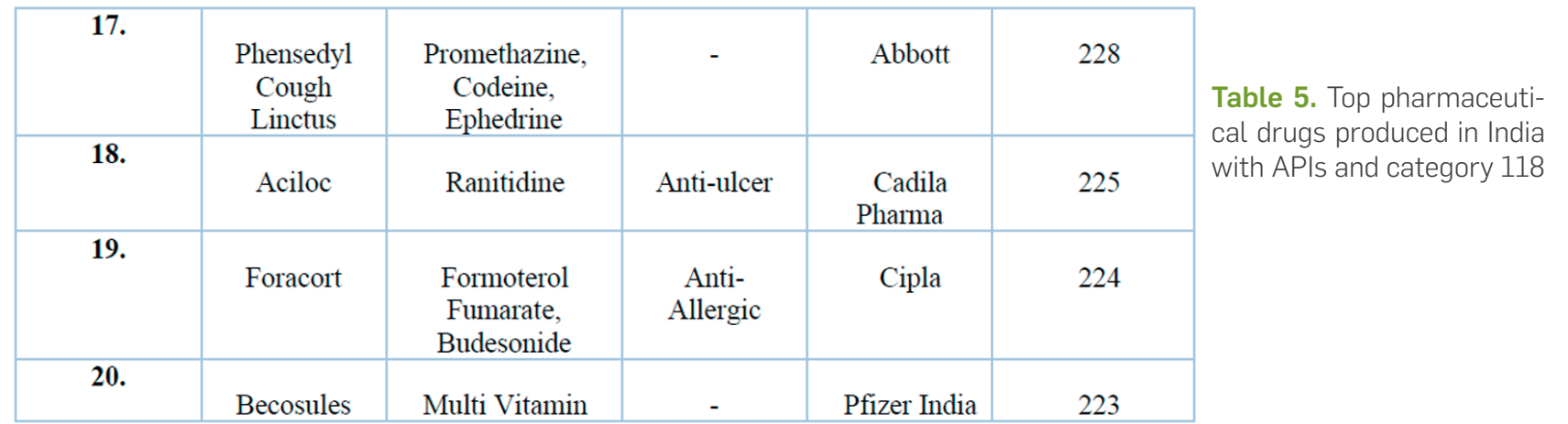

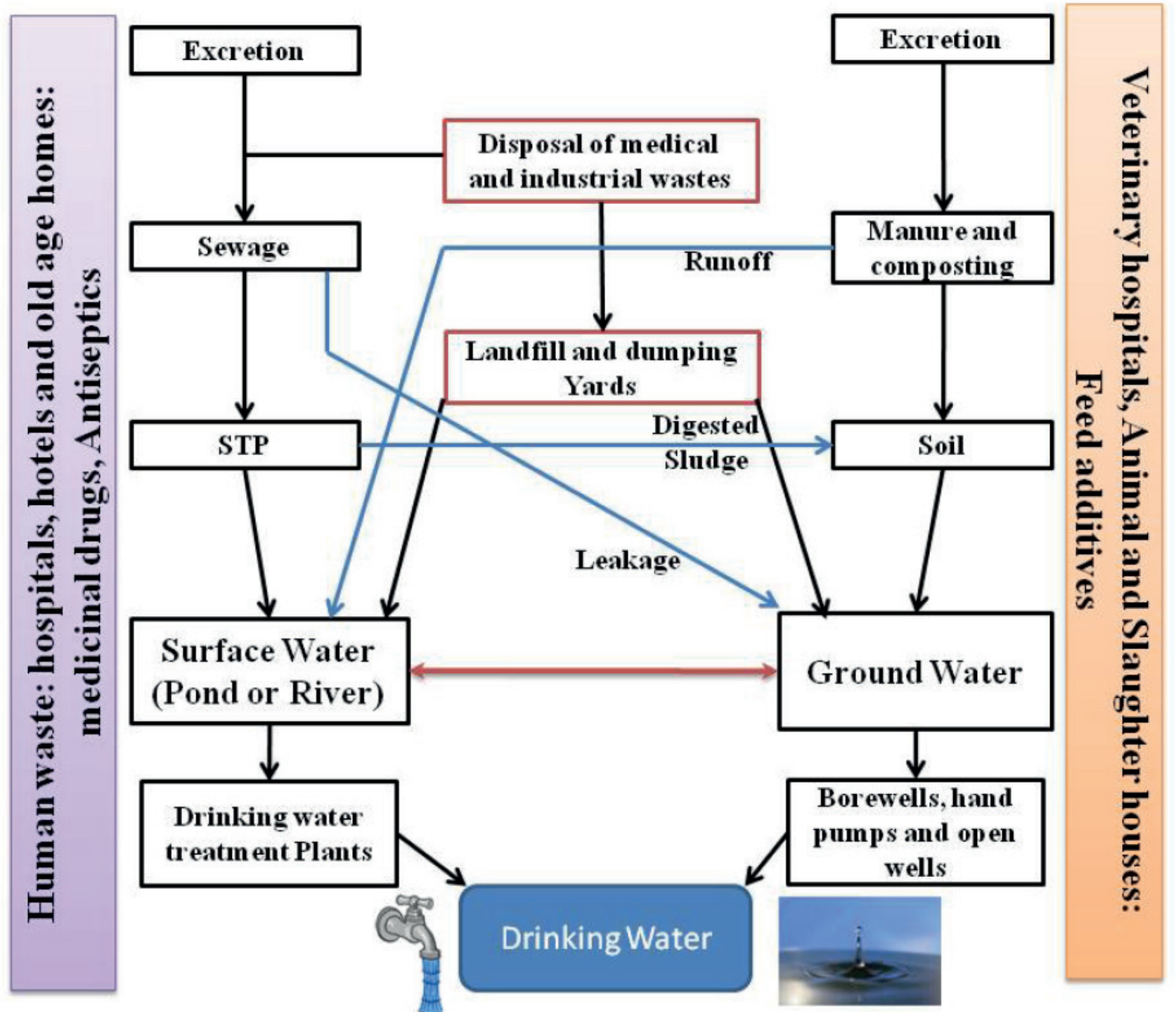

Figure 10. Pathway of transmission of pharmaceutical drugs..

found in the effluent (1130 ng/L) and sludge samples (1230ng/ L) $)^{147-149}$. In western parts of Maharastra's Nagpur, antibiotics and antidepressants were found in Nag and Pili River. More than 12 APIs are detected in 2 wastewater treatment plants of one of the largest metropolitan areas of western India. The concentration of pharmaceutical drugs varies in treatment plants because of zonal planning, seasonal diseases, medicinal patterns, lifestyle-related disorders, and rainfall ${ }^{140,141}$.

\section{Antibiotic use in India}

India is the largest consumer of antibiotics. From the past decade, $62 \%$ of usage has been an increase of antibiotics. In- dia has consumed $12.6 \times 10^{9}$ units of antibiotics during the past decade, and Per capita antibiotics consumption was 10.7 units142. The reason is poor public health systems, the high rate of tropical infectious diseases and the availability of antibiotics at cheaper rates. Indian health care system depends on doctors who routinely receive remuneration on prescribing antibiotics, and another reason is that patients are not willing to give time for the disease to cure by the body's innate immunity ${ }^{143-146}$.

Antibiotics in animal husbandry have also resulted in more excellent pathogens because of increased demand for poultry, meat, and related products. According to a report, the 
demand for poultry will be raised by $312 \%$ by 2030 . To cater to that demand, this sector is expected to be investing in Antimicrobial chemical drugs to nearly $\$ 1.2$ billion.

Dairy Industry has developed two-fold in India over the past 2 decades because of the increase in demand for milk and dairy-related products. Milk is considered a complete food because of its protein and fat contents. Nowadays, antibiotics are being used frequently in lactating animals to promote animal health, treatment and control of the infectious disease. Mastitis is a significant disease in dairy animals where the treatment involves antibiotics to mammary glands. Other reasons include using dosage deviations from recommended prescriptions, using antibiotics as preservatives, maintaining incorrect cleaning orders, and veterinary errors ${ }^{147-149}$

\section{Consequences of Excessive use of Antibiotics}

Antibiotics are used to cure diseases that are caused by microorganisms, especially bacteria. Bacteria undergo fast mutation to resist the activity of antibiotic medication is called Antibiotic resistance (A.R.) organisms. In some instances, bacteria that resist multiple antibiotics are called multi-drug-resistant (MDR). If bacteria survive in an extensive antimicrobial environment, they are called superbugs or extensive drug-resistant organisms (XDRs). For bacteria with Antibiotic resistance activity, Staphylococcus aureus, Enterococcus sp., and Multidrug-resistant Mycobacterium tuberculosis (MDR-TB) are a few examples ${ }^{149}$

The evolution of antibiotic resistance (A.R.) and expression of AR Gene in nature has led to significant public health problems around the Global ${ }^{150-152}$. If the A.R. gene is integrated into a gene transmission element and can spread to non-resistant species, turn them into Antibiotic-resistant organisms (ARO); for this character, these organisms are making their names in emerging pollutants (EMPs) list ${ }^{153-155}$.

This crisis has led to the differential use of anti- microbial drugs in therapeutic and non-therapeutic purposes at clinical and non-clinical settings. Previously researches were focused on the emergence of these bacteria in hospitals and dumping sites of pharmaceutical wastes. From the last 5 years focus of research shifted to the overall environment, which acts as a site for antimicrobial resistance evolutions. Researchers have found the various bacteria with A.R. genes in environmental samples in natural ecosystems such as sediments, soils, ground, surface, marine and drinking water ${ }^{156-165}$.

\section{Personal care products (PCPs)}

According to E.U. Regulation 1223/2009 (article 2), "cosmetic product means any substance or mixture intended to be placed in contact with the external parts of the human body (epidermis, hair system, nails, lips and external genital organs) or with the teeth and the mucous membranes of the oral cavity with a view exclusively or mainly to cleaning them, perfuming them, changing their appearance, protecting them, keeping them in good condition or correcting body odors"166.

Substances such as pharmaceuticals, personal care and other endocrine-disrupting compounds products enter the environment from different sources such as:

\section{(i) Effluents from wastewater treatment plants}

(ii) Leakage from septic tanks or landfill sites

(iii) Surface water run-off

\section{(iv) Direct discharge into waters.}

These species can also be chemically degraded by microorganisms or by U.V. light action ${ }^{167}$.

Personal care products can reach the wastewater system through multiple routes. Products such as shampoos, body washes, and toothpaste are directly washed down the drain during and after use. Products like cosmetics and hand lotions can be washed down the drain as well during a routine. The chemicals that can penetrate the body and are then excreted can also enter the wastewater system through toilet ${ }^{168}$.

The environmental safety of household products is assessed based on the ecological properties of their many components. Two fundamental issues determine their environmental safety: the environmental fate and potential effects on the environment. The environmental fate of chemical substances depends mainly on the physicochemical properties, such as water solubility, adsorption behavior, and volatility, and on their degradability, which is overwhelmingly affected by microorganisms (biological degradation) present in sewage treatment plants, surface waters, and soils. These fate-relevant properties control the distribution of a chemical in the environmental compartments (water, soil, air) and its final removal by degradation processes.

The second assessment aspect, the potential impact of a chemical on the organisms living in the environmental compartments, also depends on substance-specific properties, i.e., ecotoxicity. Data from standardized tests on representative organisms are required by European chemical legislation ${ }^{169}$.

\section{Disinfectants}

Triclosan (TCS) and triclocarban (TCC) are diphenyl ethers used as anti-microbials in soaps, deodorants, skin creams, toothpaste and plastics. TCS and TCC are among the top 10 most commonly detected organic wastewater compounds for frequency and concentration. A study monitoring 95 compounds in surface water throughout the United States found TCS to be one of the most frequently detected compounds with surface water concentrations as high as $2.3 \mathrm{ppb}$ TCC has been used in PCPs since 1957 and has been observed in surface water at concentrations up to $6.75 \mathrm{ppb}$. It is believed that TCC occurs as frequently in WWTP effluent and surface water as TCS: though, until 2004, TCC could not be detected at low levels (ppb). However, TCC has been detected at higher concentrations and more frequently in WWTP effluent and surface water than TCS or M-TCS over the last 10 years. Acute toxicity of TCS and biphenylol has been examined in invertebrates, fish, amphibians, algae, and plants ${ }^{170,171}$.

\section{Fragrances}

The most used fragrances are synthetic musks. Synthetic musks are used in a wide range of products, including deodorants, soaps, and detergents. The most commonly used nitro musks are musk xylene (MX) and musk ketone (M.K.), whereas musk ambrette (M.A.), musk moskene (MM), and musk tibetene (M.T.) are used less frequently. Nitro musks however are slowly being phased out due to their environmental persistence and potential toxicity to aquatic species. Polycyclic musks are currently used in higher quantities than nitro musks with celestolide (ABDI), galaxolide (HHCB) and toxalide (AHTN) used most commonly and traseloide (ATII), phantolide (AHMI), and cashmeran (DPMI) used less often. HHCB and AHTN production alone has been estimated at 1 million pounds per year and has thus been placed on the High Production Volume List 
by the USEPA (the United States Environmental Protection Agency). Nitro and polycyclic musks are water-soluble, but high octanol-water coefficients (log Kow $=3.8$ for M.K. and 5.4-5.9 for polycyclic musks) indicate high potential for bioaccumulation in aquatic species ${ }^{75,170-172}$.

\section{Insect repellents}

$\mathrm{N}, \mathrm{N}$-diethyl-m-toluamide (DEET) is the most common active ingredient in insect repellents and is routinely detected in surface waters. DEET is relatively persistent in the aquatic environment, but unlike many other PCPs (i.e., fragrances and U.V. filters) DEET has a low BCF and is likely not accumulated into aquatic organisms. DEET has been regularly detected in the effluent (95\% of analyzed samples) and surface water (65\% of all analyzed samples) with median concentrations of approximately $0.2 \mathrm{ppb}$ and $55 \mathrm{ppb}$, respectively. The only other insect repellent detected in WWTP effluent or surface water is 1,4-dichlorobenzene. 1,4-dichlorobenzene has been detected in surface water ( $40 \%$ of surface water screened), receiving significant inputs of WWTP effluent at concentrations up to $0.28 \mathrm{ppb}^{170,173}$.

\section{Preservatives}

Parabens (alkyl-p-hydroxybenzoates) are antimicrobial preservatives used in cosmetics, toiletries, pharmaceuticals, and food. There are currently seven different types of parabens in use (benzyl, butyl, ethyl, isobutyl, isopropyl, methyl, and propyl). Only a handful of studies have examined paraben concentrations in WWTP and surface water. The most significant concentrations of parabens have been identified in surface water with concentrations ranging from 15 to $400 \mathrm{ppb}$ depending on paraben, whereas effluent had lower concentrations ranging from 50 to $85 \mathrm{ppb}^{172}$.

\section{U.V. filters}

U.V. filters are used in sunscreen products and cosmetics to protect from U.V. radiation and can be either organic (absorb U.V. radiation, e.g. methyl benzylidene camphor) or inorganic micropigments (reflect U.V. radiation, e.g. ZnO, TiO2). U.V. filters are well known to bioaccumulate, and recent studies have also indicated the potential for estrogenic activity. In vitro assays using fish, MCF-7 cell lines indicate five UV-A and UV-B sunscreens (BP3, homosalate (HMS), 4MBC, octyl-methoxycinnamate and octyl-dimethyl-PABA) have the potential to cause estrogenic effects ${ }^{173}$.

\section{Additional compounds}

Three additional PCPs have been identified in surface water in the U.S. by United States Geologic Survey researchers. The fixative benzophenone was detected most frequently (67.5\% of samples in one study), whereas the flavorant menthol was detected at the highest concentrations (1.3 ppb). The other compound detected in the surface water is methyl salicylate (wintergreen flavoring and liniment), although it has only been detected at low concentrations and in a few environmental samples ${ }^{75}$

\section{Conclusions}

Emerging micropollutants are the problems of present living conditions and lifestyle changes of human beings. The EMPs generated from every human activity like agriculture, healthcare, and sanitation which most of them ends them in water through the sewer lines or at water bodies. Fortunately, the distribution of EMPs through the air is negligible except during the arial dispersions. The detections of these compounds are significantly less or available in smaller quantity makes them harder to regulate.

Pesticides and other crop protection chemicals are used extensively in agricultural practices and gardening, entering the soil and reaching water through run-off. Air dispersion of pesticides are not much into concern as most of them disintegrate due to sunlight and eventually settle on to the soil.

Health care and hygienic products from hospitals or residential areas are directly entering into sewers, like APIs antibiotics or endocrine disrupting substances that show amplified effects even at lower concentrations. These compounds are usually used in an unregulated manner and disposed of without treatment increases the risk of exposure.

Over the few years, nations have been working on identifying and regulating these EMPs. Countries in Europe and the USA are training their human resources and capacities for identifying and handling these pollutants. Developing countries like India are facing the problem of EMPs in various parts and are coming forward to create legislation to reduce the generation of EMPs.

\section{Bibliographic references}

1. Drangert J-O, Cronin AA. Use and abuse of the urban groundwater resource: Implications for a new management strategy. Hydrogeol J 2004 121. 2004;12(1):94-102. doi:10.1007/S10040-003-0307-Z

2. Philip JM, Aravind UK, Aravindakumar CT. Emerging contaminants in Indian environmental matrices - A review. Chemosphere. 2018;190:307-326. doi:10.1016/J.CHEMOSPHERE.2017.09.120

3. Tröger R, Klöckner P, Ahrens L, Wiberg K. Micropollutants in drinking water from source to tap - Method development and application of a multiresidue screening method. Sci Total Environ. 2018;627:1404-1432. doi:10.1016/J.SCITOTENV.2018.01.277

4. Stuart M, Lapworth D, Crane E, Hart A. Review of risk from potential emerging contaminants in UK groundwater. Sci Total Environ. 2012;416:1-21. doi:10.1016/J.SCITOTENV.2011.11.072

5. Drangert JO, Cronin AA. Use and abuse of the urban groundwater resource: Implications for a new management strategy. Hydrogeol J. 2004;12(1):94-102. doi:10.1007/S10040-003-0307-Z

6. Ellis JB. Pharmaceutical and personal care products (PPCPs) in urban receiving waters. Environ Pollut. 2006;144(1):184-189. doi:10.1016/J.ENVPOL.2005.12.018

7. Y W, P W, KD H. Fate and biological effects of silver, titanium dioxide, and C60 (fullerene) nanomaterials during simulated wastewater treatment processes. J Hazard Mater. 2012;201-202:1622. doi:10.1016/J.JHAZMAT.2011.10.086

8. Glassmeyer ST, Furlong ET, Kolpin DW, et al. Nationwide reconnaissance of contaminants of emerging concern in source and treated drinking waters of the United States. Sci Total Environ. 2017;581-582:909-922. doi:10.1016/J.SCITOTENV.2016.12.004

9. Osenbrück K, Gläser HR, Knöller K, et al. Sources and transport of selected organic micropollutants in urban groundwater underlying the city of Halle (Saale), Germany. Water Res. 2007;41(15):3259-3270. doi:10.1016/J.WATRES.2007.05.014

10. Verliefde A, Cornelissen E, Amy G, Van der Bruggen B, van Dijk $H$. Priority organic micropollutants in water sources in Flanders and the Netherlands and assessment of removal possibilities with nanofiltration. Environ Pollut. 2007;146(1):281-289. doi:10.1016/J.ENVPOL.2006.01.051

11. Ikehata K, El-Din MG, Snyder SA. Ozonation and advanced oxidation treatment of emerging organic pollutants in water and wastewater. Ozone Sci Eng. 2008;30(1):21-26. doi:10.1080/01919510701728970

12. Reinstorf F, Strauch G, Schirmer K, et al. Mass fluxes and spatial trends of xenobiotics in the waters of the city of Halle, Germany. Environ Pollut. 2008;152(2):452-460. doi:10.1016/J.ENVPOL.2007.05.033 
13. Schirmer K, Schirmer M. Who is chasing whom? A call for a more integrated approach to reduce the load of micro-pollutants in the environment. Water Sci Technol. 2008;57(1):145-150. doi:10.2166/WST.2008.826

14. Musolff A, Leschik S, Möder M, Strauch G, Reinstorf F, Schirmer M. Temporal and spatial patterns of micropollutants in urban receiving waters. Environ Pollut. 2009;157(11):3069-3077. doi:10.1016/J.ENVPOL.2009.05.037

15. Wille K, De Brabander HF, Vanhaecke L, De Wulf E, Van Caeter $\mathrm{P}$, Janssen CR. Coupled chromatographic and mass-spectrometric techniques for the analysis of emerging pollutants in the aquatic environment. TrAC Trends Anal Chem. 2012;35:87-108. doi:10.1016/J.TRAC.2011.12.003

16. Chen J, Luo W, Yu S, et al. Synergistic effect of photocatalysis and pyrocatalysis of pyroelectric $\mathrm{ZnSnO3}$ nanoparticles for dye degradation. Ceram Int. 2020;46(7):9786-9793. doi:10.1016/j.ceramint.2019.12.251

17. Amy Pruden *, Ruoting Pei, Heather Storteboom and, Carlson KH. Antibiotic Resistance Genes as Emerging Contaminants: Studies in Northern Colorado†. Environ Sci Technol. 2006:40(23):7445-7450. doi:10.1021/ES060413L

18. Emerging substances | NORMAN. Accessed July 19, 2021. https://www.norman-network.net/?q=node/19

19. Larsson DGJ. Pollution from drug manufacturing: review and perspectives. Philos Trans R Soc B Biol Sci. 2014:369(1656). doi:10.1098/RSTB.2013.0571

20. Blair BD, Crago JP, Hedman CJ, Klaper RD. Pharmaceuticals and personal care products found in the Great Lakes above concentrations of environmental concern. Chemosphere. 2013;93(9):21162123. doi:10.1016/J.CHEMOSPHERE.2013.07.057

21. Carvalho ARM, Cardoso V V., Rodrigues A, Ferreira E, Benoliel $\mathrm{MJ}$, Duarte EA. Occurrence and analysis of endocrine-disrupting compounds in a water supply system. Environ Monit Assess 2015 1873. 2015;187(3):1-8. doi:10.1007/S10661-015-4374-0

22. Westhof L, Köster S, Reich M. Occurrence of micropollutants in the wastewater streams of cruise ships. Emerg Contam. 2016;2(4):178-184. doi:10.1016/J.EMCON.2016.10.001

23. WJ C, HM S, D H, et al. Prevalence of historical and replacement brominated flame retardant chemicals in New York City homes. Emerg Contam. 2017;3(1):32-39. doi:10.1016/J.EMCON.2017.01.001

24. McGrath TJ, Morrison PD, Ball AS, Clarke BO. Detection of novel brominated flame retardants (NBFRs) in the urban soils of Melbourne, Australia. Emerg Contam. 2017;3(1):23-31. doi:10.1016/J. EMCON.2017.01.002

25. Iceland: chapter 27-Environment Screening report Iceland Chapter 27-Environment Date of screening meetings. Published online 2011.

26. I OF THE EUROPEAN PARLIAMENT AND OF THE COUNCIL of 12 August 2013 amending Directives 2000/60/EC and 2008/105/EC as regards priority substances in the field of water policy (Text with EEA relevance)

27. Control Agency M. Q7 Good Manufacturing Practice Guidance for Active Pharmaceutical Ingredients Guidance for Industry. Published online 2016. Accessed July 19, 2021. http://www.fda.gov/ Drugs/GuidanceComplianceRegulatoryInformation/Guidances/ default.htmhttp://www.fda.gov/BiologicsBloodVaccines/GuidanceComplianceRegulatoryInformation/Guidances/default.htm

28. Einschlag FSG. Waste Water - Evaluation and Management. Waste Water - Eval Manag. Published online April 1, 2011 doi:10.5772/2051

29. K N-O, DS A. Lessons learned from more than two decades of research on emerging contaminants in the environment. J Hazard Mater. 2016;316:242-251. doi:10.1016/J.JHAZMAT.2016.04.058

30.Gogoi A, Mazumder P, Tyagi VK, Tushara Chaminda GG, An AK, Kumar M. Occurrence and fate of emerging contaminants in water environment: A review. Groundw Sustain Dev. 2018;6:169180. doi:10.1016/J.GSD.2017.12.009

31. Capri E, Karpouzas D. Pesticide risk assessment in rice paddies. Published online 2007:247.
32. K N, Y M, K I, M K, T M, N S. Selecting pesticides for inclusion in drinking water quality guidelines on the basis of detection probability and ranking. Environ Int. 2014;63:114-120. doi:10.1016/J. ENVINT.2013.10.019

33. I Zurlytè and A Laukaitienè. Use of Sub National Indicator to Impove Public Health in Europu (UNIPHE).

34.R V, A F, S O, M V. Predicting pesticide environmental risk in intensive agricultural areas. I: Screening level risk assessment of individual chemicals in surface waters. Environ Sci Technol. 2009;43(2):522-529. doi:10.1021/ES801855F

35. Gramatica P. Di Guardo A. Screening of pesticides for environmental partitioning tendency. Chemosphere. 2002;47(9):947956. doi:10.1016/S0045-6535(02)00007-3

36. Reus JAWA, Leendertse PC. The environmental yardstick for pesticides: a practical indicator used in the Netherlands. Crop Prot. 2000;19(8-10):637-641. doi:10.1016/S0261-2194(00)00084-3

37. Reus J, Leendertse P, Bockstaller C, et al. Comparison and evaluation of eight pesticide environmental risk indicators developed in Europe and recommendations for future use. Agric Ecosyst Environ. 2002;90(2):177-187. doi:10.1016/S0167-8809(01)00197-9

38. Contaminants of Emerging Concern including Pharmaceuticals and Personal Care Products I US EPA. Accessed July 19, 2021. https://www.epa.gov/wqc/contaminants-emerging-concern-including-pharmaceuticals-and-personal-care-products

39. Stephen CE, Mount DI, Hansen DJ, Gentile JR, Chapman GA Brungs WA. Guidelines for Deriving Numerical National Water Quality Criteria for the Protection Of Aquatic Organisms and Their Uses. Published online 2010. Accessed July 19, 2021. http://www.nodc.noaa.gov/General/CDR-detdesc/taxonomic-v8. html.

40.white paper aquatic life criteria for contaminants of emerging concern part i general challenges and recommendations Prepared by the OW/ORD Emerging Contaminants Workgroup NOTICE THIS DOCUMENT IS AN INTERNAL PLANNING DOCUMENT. Published online 2008.

41. Johnson Administrator SL, Administrator Johnson D. The Honorable Subject: SAB Advisory on Aquatic Life Water Quality Criteria for Contaminants of Emerging Concern. Published online 2008.

42. Kitamura T. Water Environment Management in Japan WEPA Dialogue in Sri Lanka. Published online 2012.

43. Water Pollution Control Law_Chapter I [MOE]. Accessed July 19, 2021. https://www.env.go.jp/en/laws/water/wlaw/ch1.html

44.Bester K, Scholes L, Wahlberg C, McArdell CS. Sources and Mass Flows of Xenobiotics in Urban Water Cycles-an Overview on Current Knowledge and Data Gaps. Water, Air, Soil Pollut Focus 2008 85. 2008:8(5):407-423. doi:10.1007/S11267-008-9189-3

45.T H, D F. Contribution of effluents from hospitals and private households to the total loads of diclofenac and carbamazepine in municipal sewage effluents--modeling versus measurements. J Hazard Mater. 2005;122(3):211-218. doi:10.1016/J. JHAZMAT.2005.03.007

46. Ruthann A. Rudel *, †, Steven J. Melly †, Paul W. Geno ‡, Gang Sun $\neq$ and, Brody† JG. Identification of Alkylphenols and Other Estrogenic Phenolic Compounds in Wastewater, Septage, and Groundwater on Cape Cod, Massachusetts. Environ Sci Technol. 1998;32(7):861-869. doi:10.1021/ES970723R

47. Putschew A, Wischnack S, Jekel M. Occurrence of triiodinated $\mathrm{X}$-ray contrast agents in the aquatic environment. Sci Total Environ. 2000;255(1-3):129-134. doi:10.1016/S00489697(00)00461-7

48.Verlicchi P, Galletti A, Petrovic M, BarcelÓ D. Hospital effluents as a source of emerging pollutants: An overview of micropollutants and sustainable treatment options. J Hydrol. 2010;389(3-4):416428. doi:10.1016/J.JHYDROL.2010.06.005

49. AJ W, EJ M, DW K, SD C. The occurrence of antibiotics in an urban watershed: from wastewater to drinking water. Sci Total Environ. 2009;:407(8):2711-2723. doi:10.1016/J.SCITOTENV.2008.11.059

50.and TAT, Hirsch R. Occurrence and Behavior of X-ray Contrast Media in Sewage Facilities and the Aquatic Environment. Environ Sci Technol. 2000;34(13):2741-2748. doi:10.1021/ES991118M 
51. T T, $U$ von G. Editorial to special issue in Water Research: emerging contaminants in water. Water Res. 2010;44(2):351. doi:10.1016/J.WATRES.2010.01.015

52. Díaz-Cruz MS, Barceló D. Trace organic chemicals contamination in ground water recharge. Chemosphere. 2008;72(3):333-342. doi:10.1016/J.CHEMOSPHERE.2008.02.031

53.DG L, C de P, N P. Effluent from drug manufactures contains extremely high levels of pharmaceuticals. J Hazard Mater. 2007:148(3):751-755. doi:10.1016/J.JHAZMAT.2007.07.008

54.Larsson DGJ. Drug Production Facilities - An Overlooked Discharge Source for Pharmaceuticals to the Environment. Pharm Environ. Published online October 9, 2008:37-42. doi:10.1007/978-3-540-74664-5_3

55. Gasser G, Rona M, Voloshenko A, et al. Quantitative Evaluation of Tracers for Quantification of Wastewater Contamination of Potable Water Sources. Environ Sci Technol. 2010;44(10):3919-3925. doi:10.1021/ES100604C

56. S B-H, DD S, T D-P, D M. Occurrence of steroid hormones and antibiotics in shallow groundwater impacted by livestock waste control facilities. J Contam Hydrol. 2011;123(3-4):94-103. doi:10.1016/J.JCONHYD.2010.12.010

57. Kim K-R, Owens G, Kwon S-I, So K-H, Lee D-B, Ok YS. Occurrence and Environmental Fate of Veterinary Antibiotics in the Terrestrial Environment. Water, Air, Soil Pollut 2010 2141. 2010;214(1):163174. doi:10.1007/S11270-010-0412-2

58. Watanabe N, Bergamaschi BA, Loftin KA, Meyer MT, Harter T. Use and Environmental Occurrence of Antibiotics in Freestall Dairy Farms with Manured Forage Fields. Environ Sci Technol. 2010;44(17):6591-6600. doi:10.1021/ES100834S

59. N W, TH H, BA B. Environmental occurrence and shallow ground water detection of the antibiotic monensin from dairy farms. J Environ Qual. 2008;37(5 Suppl):S-78-S-85. doi:10.2134/ JEQ2007.0371

60.A BRIEF REPORT ON PHARMACEUTICAL INDUSTRY IN INDIA. Published online 2014. Accessed July 19, 2021. www.pharmaceuticals.gov.in

61. Ahel M, Jeličić I. Phenazone analgesics in soil and groundwater below a municipal solid waste landfill. ACS Symp Ser. 2001;791:100-115. doi:10.1021/BK-2001-0791.CH006

62. Ahel M, Mikac N, Cosovic B, Prohic E, Soukup V. The impact of contamination from a municipal solid waste landfill (zagreb, croatia) on underlying soil. Water Sci Technol. 1998;37(8):203-210. doi:10.1016/S0273-1223(98)00260-1

63. Barnes KK, Christenson SC, Kolpin DW, et al. Pharmaceuticals and other organic wastewater contaminants within a leachate plume downgradient of a municipal landfill. Groundw Monit Remediat. 2004;24(2):119-126. doi:10.1111/J.1745-6592.2004 TB00720.X

64. Buszka PM, Yeskis DJ, Kolpin DW, Furlong ET, Zaugg SD, Meyer MT. Waste-indicator and pharmaceutical compounds in landfill-leachate-affected ground water near Elkhart, Indiana, 2000-2002. Bull Environ Contam Toxicol. 2009;82(6):653-659. doi:10.1007/S00128-009-9702-Z

65. JW N, B D, JP B, et al. Observed and modeled effects of $\mathrm{pH}$ on bioconcentration of diphenhydramine, a weakly basic pharmaceutical, in fathead minnows. Environ Toxicol Chem. 2015;34(6):14251435. doi:10.1002/ETC.2948

66. B D, SP H, A L, et al. Bioaccumulation of human pharmaceuticals in fish across habitats of a tidally influenced urban bayou. Environ Toxicol Chem. 2016;35(4):966-974. doi:10.1002/ETC.3221

67. B V, JV H, RD R. Behaviour and fate of tetracycline in river and wetland waters on the Canadian Northern Great Plains. J Environ Sci Health A Tox Hazard Subst Environ Eng. 2007;42(2):109-117. doi:10.1080/10934520601011163

68. Hamscher G, Hartung J. Veterinary Antibiotics in Dust: Sources, Environmental Concentrations, and Possible Health Haz ards. Pharm Environ. Published online October 9, 2008:95-102. doi:10.1007/978-3-540-74664-5 7

69.Drinking-water. Accessed July 19, 2021. https://www.who.int/ news-room/fact-sheets/detail/drinking-water
70.Progress on Drinking Water, Sanitation and Hygiene Update and SDG Baselines. Published online 2017. Accessed July 19, 2021. http://apps.who.int/bookorders.

71. Pesticide residues in food. Accessed July 19, 2021. https:// www.who.int/news-room/fact-sheets/detail/pesticide-residues-in-food

72. India's antibiotic use in animals to increase $82 \%$ by 2030 . Accessed July 19, 2021. https://www.downtoearth.org.in/news/health/india-s-antibiotic-use-in-animals-to-increase-83-by-2030-58785

73. Enyoh CE, Verla AW, Qingyue W, et al. An overview of emerging pollutants in air: Method of analysis and potential public health concern from human environmental exposure. Trends Environ Anal Chem. 2020;28:e00107. doi:10.1016/J.TEAC.2020.E00107

74.W W. Medical consequences of antibiotic use in agriculture. Science. 1998:279(5353):996-997. doi:10.1126/SCIENCE.279.5353.996

75. Daughton CG, Ternes TA. Pharmaceuticals and personal care products in the environment: agents of subtle change? Environ Health Perspect. 1999:107(Suppl 6):907. doi:10.1289/ EHP.99107S6907

76. Li W, Nanaboina V, Zhou Q, Korshin G V. Effects of Fenton treatment on the properties of effluent organic matter and their relationships with the degradation of pharmaceuticals and personal care products. Water Res. 2012;46(2):403-412. doi:10.1016/J. WATRES.2011.11.002

77. J S, H F, U M, H W, RD N. Toxic effects of the non-steroidal anti-inflammatory drug diclofenac. Part I: histopathological alterations and bioaccumulation in rainbow trout. Aquat Toxicol. 2004;68(2):141-150. doi:10.1016/J.AQUATOX.2004.03.014

78. GC Y, CH Y, CL W. Monitoring and removal of residual phthalate esters and pharmaceuticals in the drinking water of Kaohsiung City, Taiwan. J Hazard Mater. 2014;277:53-61. doi:10.1016/J. JHAZMAT.2014.03.005

79. AV K, P S, SF P, L T, D F. Bisphenol-A: an estrogenic substance is released from polycarbonate flasks during autoclaving. Endocrinology. 1993;132(6):2279-2286. doi:10.1210/END0.132.6.8504731

80.P S, JP S. Several environmental oestrogens are also anti-androgens. J Endocrinol. 1998;158(3):327-339. doi:10.1677/ JOE.0.1580327

81. EJ R, J P, J O, J A, JP S. Some alkyl hydroxy benzoate preservatives (parabens) are estrogenic. Toxicol Appl Pharmacol. 1998:153(1):12-19. doi:10.1006/TAAP.1998.8544

82. Okumura T, Nishikawa Y. Gas chromatography-mass spectrometry determination of triclosans in water, sediment and fish samples via methylation with diazomethane. Anal Chim Acta. 1996;325(3):175-184. doi:10.1016/0003-2670(96)00027-X

83. LM M, M O, SB L. Triclosan targets lipid synthesis. Nature. 1998:394(6693):531-532. doi:10.1038/28970

84. Tandukar M, Oh S, Tezel U, Konstantinidis KT, Pavlostathis SG. Long-Term Exposure to Benzalkonium Chloride Disinfectants Results in Change of Microbial Community Structure and Increased Antimicrobial Resistance. Environ Sci Technol. 2013;47(17):97309738. doi:10.1021/ES401507K

85.3 Investment and Saving Slowdowns and Recoveries: Cross-Country Insights for India.

86. Knowledge and Strategic Partner Next Generation Indian Agriculture-Role of Crop Protection Solutions Indian Agrochemical Industry. Published online 2016.

87. Murthal C. Government of India, Ministry of Chemicals \& Fertilizers Department Annual Report -2016-17.

88. Devi PI, Thomas J, Raju RK. Pesticide consumption in India: A spatiotemporal analysis. Agric Econ Res Rev. 2017;30(1):163. doi:10.5958/0974-0279.2017.00015.5

89.Gol. The Pesticide Management Bill 2008.

90.Statistical Database of Directorate of Plant Protection, Quarantine \& Storage, GOl. Accessed July 19, 2021. http://ppqs.gov.in/ statistical-database

91. State of Agriculture in India. Published online 2017

92. Gol. The Insecticides Act, 1968.

93. Gol. Insecticides Rules, 1971 
94. List of registered pesticides.

95. Center fo Science and Environment. State of Pesticide Regulations in India.

96. Sola P, Mvumi BM, Ogendo JO, et al. Botanical pesticide production, trade and regulatory mechanisms in sub-Saharan Africa: making a case for plant-based pesticidal products. Food Secur 2014 63. 2014;6(3):369-384. doi:10.1007/S12571-014-0343-7

97. CE H, CT E, K C. A review of the global pesticide legislation and the scale of challenge in reaching the global harmonization of food safety standards. Integr Environ Assess Manag. 2015;11(4):525536. doi:10.1002/IEAM.1635

98.Directorate-General H\& FS. Guidance Document on Preparing Dossiers for the Approval of a Chemical New Active Substance for the Renewal of Approval of a Chemical Active Substance According to Regulation. European Commission; 2021. https:// ec.europa.eu/food/system/files/2021-03/pesticides_ppp_appproc_guide_doss_10181.pdf

99. Maximum Residue Limits (MRL) Database I USDA Foreign Agricultural Service. Accessed July 19, 2021. https://www.fas.usda. gov/maximum-residue-limits-mrl-database

100. [USC05] 7 USC Ch. 6: INSECTICIDES AND ENVIRONMENTAL PESTICIDE CONTROL. Accessed July 19, 2021. https://uscode.house.gov/view.xhtml?path=/prelim@title7/chapter6\&edition=prelim

101. Environmental Protection Agency 40 CFR Part 63 National Emission Standards for Hazardous Air Pollutant Emissions: Group IV Polymers and Resins; Pesticide Active Ingredient Production; and Polyether Polyols Production; Final Rule. Published online 2010. Accessed July 19, 2021. http://www.regulations.gov

102. Regulation of Pesticide Residues on Food I US EPA. Accessed July 19, 2021. https://www.epa.gov/pesticide-tolerances

103. US-EPA. Setting Tolerances for Pesticide Residues in Foods I US EPA. Accessed November 3, 2021. https://www.epa.gov/pesticide-tolerances/setting-tolerances-pesticide-residues-foods

104. Ota H. Historical Development of Pesticides in Japan and Animal Health Department 1996 Mitsubishi Chemical Industries Co., Ltd., director of Agricultural Research Laboratory. Dir Sci Technol Off. Published online 1999.

105. THIS REPORT CONTAINS ASSESSMENTS OF COMMODITY AND TRADE ISSUES MADE BY USDA STAFF AND NOT NECESSARILY STATEMENTS OF OFFICIAL U.S. GOVERNMENT POL ICY Required Report-public distribution GAIN Report Number JA8113 Japan Food and Agricultural Import Regulations and Standards Report 2018 FAIRS Annual Country Report. Accessed July 19, 2021. http://gain.fas.usda.gov/Pages/Default.aspx.

106. Agarwal A, Prajapati R, Singh OP, Raza SK, Thakur LK. Pesticide residue in water-a challenging task in India. Environ Monit Assess 2015 1872. 2015;187(2):1-21. doi:10.1007/S10661-0154287-Y

107. Jiang JQ, Zhou Z, Sharma VK. Occurrence, transportation, monitoring and treatment of emerging micro-pollutants in waste water - A review from global views. Microchem J. 2013;110:292 300. doi:10.1016/J.MICROC.2013.04.014

108. Lishman L, Smyth SA, Sarafin K, et al. Occurrence and reductions of pharmaceuticals and personal care products and estrogens by municipal wastewater treatment plants in Ontario, Canada. Sci Total Environ. 2006;367(2-3):544-558. doi:10.1016/J SCITOTENV.2006.03.021

109. Halling-Sørensen B, Nors Nielsen S, Lanzky PF, Ingerslev F, Holten Lützhøft HC, Jørgensen SE. Occurrence, fate and effects of pharmaceutical substances in the environment- A review. Chemosphere. 1998:36(2):357-393. doi:10.1016/S00456535(97)00354-8

110. D F-K, S M, A N. Pharmaceutical residues in environmental waters and wastewater: current state of knowledge and future research. Anal Bioanal Chem. 2011;399(1):251-275. doi:10.1007/ S00216-010-4300-9

111. KE A, AB B, AR B, et al. Assessing the exposure risk and impacts of pharmaceuticals in the environment on individuals and ecosystems. Biol Lett. 2013:9(4). doi:10.1098/RSBL.2013.0492
112. Neuausgabe KF. Ökotoxikologie Umweltchemie-Toxikologie-Ökologie. Accessed July 20, 2021. www.beck.de

113. Randhawa G, Chanana A, Kullar JS. Ecopharmacology and its Future Forensic Implications: - An Emerging Science. undefined. Published online 2012

114. Pharmaceuticals in drinking-water

115. Küster A, Adler N. Pharmaceuticals in the environment: scientific evidence of risks and its regulation. Philos Trans R Soc B Biol Sci. 2014;369(1656). doi:10.1098/RSTB.2013.0587

116. KümmererK. Pharmaceuticals in the Environment. http://dxdoi.org/101146/annurev-environ-052809-161223. 2010;35:5775. doi:10.1146/ANNUREV-ENVIRON-052809-161223

117. Here are top 20 generic drugs in India, anti-diabetic medicines top list I Business Standard News. Accessed July 20, 2021. https://www.business-standard.com/article/companies/hereare-top-20-generic-drugs-in-india-anti-diabetic-medicines-toplist-117051300977_1.html

118. Pharma Industry in India: Pharma Sector Overview, Market Size, Analysis...। IBEF. Accessed July 20, 2021. https://www.ibef. org/industry/pharmaceutical-india.aspx

119. Healthcare Industry in India, Indian Healthcare Sector, Services. Accessed July 20, 2021. https://www.ibef.org/industry/ healthcare-india.aspx

120. Hyderabad's pharmaceutical pollution crisis. Accessed July 20, 2021. www.changingmarkets.org

121. A call for action: India's pharma pollution crisis I Nordea. Accessed July 20, 2021. https://insights.nordea.com/en/sustainability/a-call-for-action-indias-pharma-pollution-crisis/

122. DG JL, J F. Transparency throughout the production chain-a way to reduce pollution from the manufacturing of pharmaceuticals? Regul Toxicol Pharmacol. 2009;53(3):161-163. doi:10.1016/J.YRTPH.2009.01.008

123. Big Pharma's pollution is creating deadly superbugs while the world looks the other way - The Bureau of Investigative Journalism (en-GB). Accessed July 20, 2021. https://www.thebureauinvestigates.com/stories/2017-05-06/big-pharmas-pollution-iscreating-deadly-superbugs-while-the-world-looks-the-other-way

124. $C L, C B, A D$, et al. Environmental pollution with antimicrobial agents from bulk drug manufacturing industries in Hyderabad, South India, is associated with dissemination of extended-spectrum beta-lactamase and carbapenemase-producing pathogens. Infection. 2017:45(4):479-491. doi:10.1007/S15010-017-1007-2

125. PK M, AK M. Risk assessment of antibiotic residues in different water matrices in India: key issues and challenges. Environ Sci Pollut Res Int. 2014;21(12):7723-7736. doi:10.1007/S11356014-2702-5

126. BM S, GK B, S T, et al. Perfluoroalkyl substances (PFAS) in river and ground/drinking water of the Ganges River basin: Emissions and implications for human exposure. Environ Pollut. 2016:208(Pt B):704-713. doi:10.1016/J.ENVPOL.2015.10.050

127. KP S, P R, AK S, P V, S G. Occurrence of pharmaceuticals in urban wastewater of north Indian cities and risk assessment. Environ Monit Assess. 2014;186(10):6663-6682. doi:10.1007/ S10661-014-3881-8

128. KM G, A R, AA K. Contamination level of four priority phthalates in North Indian wastewater treatment plants and their fate in sequencing batch reactor systems. Environ Sci Process Impacts. 2016;18(3):406-416. doi:10.1039/C5EM00583C

129. Jindal K, Narayanam M, Singh S. A systematic strategy for the identification and determination of pharmaceuticals in environment using advanced LC-MS tools: Application to ground water samples. J Pharm Biomed Anal. 2015;108:86-96. doi:10.1016/J.JPBA.2015.02.003

130. Mutiyar PK, Mittal AK. Occurrences and fate of an antibiotic amoxicillin in extended aeration-based sewage treatment plant in Delhi, India: a case study of emerging pollutant. New pub Balaban. 2013:51(31-33):6158-6164. doi:10.1080/19443994.2013.770199

131. PK M AK M. Occurrences and fate of selected human antibiotics in influents and effluents of sewage treatment plant and effluent-receiving river Yamuna in Delhi (India). Environ Monit Assess. 2013;186(1):541-557. doi:10.1007/S10661-013-3398-6 
132. Rayaroth MP, Khalid NK, Sasi S, Aravind UK, Aravindakumar CT. Identification of Chlorophene in a Backwater Stream in Kerala (India) and its Sonochemical Degradation Studies. CLEAN - Soil, Air, Water. 2015;43(9):1338-1343. doi:10.1002/CLEN.201400508

133. Shanmugam G, Sampath S, Selvaraj KK, Larsson DGJ, Ramaswamy BR. Non-steroidal anti-inflammatory drugs in Indian rivers. Environ Sci Pollut Res. 2014;21(2):921-931. doi:10.1007/ S11356-013-1957-6

134. G S, N V. Assessment of perfluorooctanoic acid and perfluorooctane sulfonate in surface water - Tamil Nadu, India. Mar Pollut Bull. 2016;109(1):612-618. doi:10.1016/J.MARPOLBUL.2016.05.023

135. Anumol T, Vijayanandan A, Park M, Philip L, Snyder SA. Occurrence and fate of emerging trace organic chemicals in wastewater plants in Chennai, India. Environ Int. 2016;92-93:33-42. doi:10.1016/J.ENVINT.2016.03.022

136. Ma K, Salama HA, Sivaraja R, Rb V. Detection of BisphenolA in Various Environment Samples Collected from Tamil Nadu, India by Solid-Phase Extraction and GC Analysis. undefined. Published online 2013.

137. Gothwal R, Shashidhar. Occurrence of High Levels of Fluoroquinolones in Aquatic Environment due to Effluent Discharges from Bulk Drug Manufacturers. J Hazardous, Toxic, Radioact Waste. 2017;21(3):05016003. doi:10.1061/(ASCE) HZ.2153-5515.0000346

138. B S, K B, DI J, K K. Mass loading and removal of pharmaceuticals and personal care products including psychoactives, antihypertensives, and antibiotics in two sewage treatment plants in southern India. Chemosphere. 2017;167:429-437. doi:10.1016/J. CHEMOSPHERE.2016.10.026

139. Subedi B, Balakrishna K, Sinha RK, Yamashita N, Balasubramanian VG, Kannan K. Mass loading and removal of pharmaceuticals and personal care products, including psychoactive and illicit drugs and artificial sweeteners, in five sewage treatment plants in India. J Environ Chem Eng. 2015;3(4):2882-2891. doi:10.1016/J.JECE.2015.09.031

140. None GA, R D, A K. Offline solid-phase extraction for preconcentration of pharmaceuticals and personal care products in environmental water and their simultaneous determination using the reversed phase high-performance liquid chromatography method. Environ Monit Assess. 2016;188(9). doi:10.1007/ S10661-016-5510-1

141. Li J, Vento S Del, Schuster J, et al. Perfluorinated Compounds in the Asian Atmosphere. Environ Sci Technol. 2011;45(17):7241-7248. doi:10.1021/ES201739T

142. TP VB, S G, A A, et al. Global antibiotic consumption 2000 to 2010: an analysis of national pharmaceutical sales data Lancet Infect Dis. 2014:14(8):742-750. doi:10.1016/S14733099(14)70780-7

143. Laxminarayan R, Chaudhury RR. Antibiotic Resistance in India: Drivers and Opportunities for Action. PLOS Med. 2016;13(3):e1001974. doi:10.1371/JOURNAL.PMED.1001974

144. N R, N M, SA P. Drug promotional practices in Mumbai: a qualitative study. Indian J Med Ethics. 2007;4(2):57-61. doi:10.20529/IJME.2007.020

145. A K, M B, N D, et al. Point prevalence surveys of healthcare-associated infections and use of indwelling devices and antimicrobials over three years in a tertiary care hospital in India. $J$ Hosp Infect. 2014;86(4):272-274. doi:10.1016/J.JHIN.2013.12.010

146. KANUNGO S, MAHAPATRA T. BHADURI B, et al. Diarrhoea-related knowledge and practice of physicians in urban slums of Kolkata, India. Epidemiol Infect. 2014;142(2):314-326. doi:10.1017/S0950268813001076

147. Sachi S, Ferdous J, Sikder MH, Hussani SMAK. Antibiotic residues in milk: Past, present, and future. J Adv Vet Anim Res. 2019;6(3):315. doi:10.5455/JAVAR.2019.F350

148. Cows pumped with antibiotics, treated as milk machines in dairies: Report - Hindustan Times. Accessed July 20, 2021. https://www.hindustantimes.com/jaipur/cows-pumped-withantibiotics-treated-as-milk-machines-in-dairies-report/story-Fkar2U3yz8QH47JCeTDSQL.html
149. Magiorakos AP, Srinivasan A, Carey RB, et al. Multidrug-resistant, extensively drug-resistant and pandrug-resistant bacteria: An international expert proposal for interim standard definitions for acquired resistance. Clin Microbiol Infect. 2012;18(3):268-281. doi:10.1111/J.1469-0691.2011.03570.X/PDF

150. B B, J F, PE L. Urban wastewater effluent increases antibiotic resistance gene concentrations in a receiving northern European river. Environ Toxicol Chem. 2015;34(1):192-196. doi:10.1002/ETC.2784

151. Marti E, Variatza E, Balcazar JL. The role of aquatic ecosystems as reservoirs of antibiotic resistance. Trends Microbiol. 2014;22(1):36-41. doi:10.1016/J.TIM.2013.11.001

152. J L, W C, L X, PJ S, H C. Antibiotic-resistant genes and antibiotic-resistant bacteria in the effluent of urban residential areas, hospitals, and a municipal wastewater treatment plant system. Environ Sci Pollut Res Int. 2015;22(6):4587-4596. doi:10.1007/ S11356-014-3665-2

153. $Q Y, D Y, Y P, Y L, L X$. Occurrence and distribution of antibiotic-resistant bacteria and transfer of resistance genes in Lake Taihu. Microbes Environ. 2013;28(4):479-486. doi:10.1264/ JSME2.ME13098

154. JL M. Environmental pollution by antibiotics and by antibiotic resistance determinants. Environ Pollut. 2009:157(11):28932902. doi:10.1016/J.ENVPOL.2009.05.051

155. Sanderson H, Fricker C, Brown RS, Majury A, Liss SN. Antibiotic resistance genes as an emerging environmental contaminant. https://doi.org/101139/er-2015-0069. 2016;24(2):205-218. doi:10.1139/ER-2015-0069

156. DebMandal M. Antibiotic Resistance Prevalence and Pattern in Environmental Bacterial Isolates. Open Antimicrob Agents J. 2012;3(1):45-52. doi:10.2174/1876518101103010045

157. Bengtsson-Palme J, Boulund F, Fick J, Kristiansson E, Larsson DGJ. Shotgun metagenomics reveals a wide array of antibiotic resistance genes and mobile elements in a polluted lake in India. Front Microbiol. 2014;5(DEC). doi:10.3389/FMICB.2014.00648

158. Manjusha S, Sarita GB, Elyas KK, Chandrasekaran M. Multiple Antibiotic Resistances of Vibrio Isolates from Coastal and Brackish Water Areas. Am J Biochem Biotechnol. 2005;1(4):193198. doi:10.3844/AJBBSP.2005.193.198

159. Maloo A, Borade S, Dhawde R, Gajbhiye SN, Dastager SG Occurrence and distribution of multiple antibiotic-resistant bacteria of Enterobacteriaceae family in waters of Veraval coast, India. Environ Exp Biol. 2014;12:43-50.

160. S P, TS S, DC T. Antibiotic susceptibility profile of bacteria isolated from natural sources of water from rural areas of East sikkim. Indian J Community Med. 2014;39(3):156-160. doi:10.4103/0970-0218.137152

161. KC S, AJ T, S S, PS S, SR K, CS L. Geographical variation in antibiotic-resistant Escherichia coli isolates from stool, cow-dung and drinking water. Int J Environ Res Public Health. 2012:9(3):746-759. doi:10.3390/IJERPH9030746

162. C R, J F, N M, et al. Fluoroquinolones and gnr genes in sediment, water, soil, and human fecal flora in an environment polluted by manufacturing discharges. Environ Sci Technol. 2014:48(14):7825-7832. doi:10.1021/ES501452A

163. Sneha KG, Anas A, Jayalakshmy K V., et al. Distribution of multiple antibiotic resistant Vibrio spp across Palk Bay. Reg Stud Mar Sci. 2016:3:242-250. doi:10.1016/J.RSMA.2015.11.004

164. Sengupta N, Alam SI, Kumar RB, Singh L. Diversity and antibiotic susceptibility pattern of cultivable anaerobic bacteria from soil and sewage samples of India. Infect Genet Evol. 2011;11(1):64-77. doi:10.1016/J.MEEGID.2010.10.009

165. Tanner WD, VanDerslice JA, Toor D, et al. Development and field evaluation of a method for detecting carbapenem-resistant bacteria in drinking water. Syst Appl Microbiol. 2015;38(5):351357. doi:10.1016/J.SYAPM.2015.03.010

166. Juliano C, Magrini GA. Cosmetic Ingredients as Emerging Pollutants of Environmental and Health Concern. A Mini-Review. Cosmet 2017, Vol 4, Page 11. 2017;4(2):11. doi:10.3390/COSMETICS4020011 
167. Ebele AJ, Abou-Elwafa Abdallah M, Harrad S. Pharmaceuticals and personal care products (PPCPs) in the freshwater aquatic environment. Emerg Contam. 2017:3(1):1-16. doi:10.1016/J. EMCON.2016.12.004

168. Paulsen L. The Health Risks of Chemicals in Personal Care Products and Their Fate in the Environment. Published online 2015. Accessed July 20, 2021. http://digitalcommons.conncoll. edu/chemhphttp://digitalcommons.conncoll.edu/chemhp/15

169. Tolls J, Berger H, Klenk A, et al. Environmental safety aspects of personal care products-A European perspective. Environ Toxicol Chem. 2009;28(12):2485-2489. doi:10.1897/09-104.1

170. JM B, GM R. A review of personal care products in the aquatic environment: environmental concentrations and toxicity. Chemosphere. 2011;82(11):1518-1532. doi:10.1016/J.CHEMOSPHERE.2010.11.018

171. Mao H, Li H, Li Y, Li L, Yin L, Yang Z. Four typical personal care products in a municipal wastewater treatment plant in China: Occurrence, removal efficiency, mass loading and emission. Ecotoxicol Environ Saf. 2020;188:109818. doi:10.1016/J.ECOENV.2019.109818

172. Breton R, Boxall A. Pharmaceuticals and Personal Care Products in the Environment: Regulatory Drivers and Research Needs. QSAR Comb Sci. 2003:22(3):399-409. doi:10.1002/ QSAR.200390030

173. Glassmeyer* ST, Furlong ET, Kolpin DW, et al. Transport of Chemical and Microbial Compounds from Known Wastewater Discharges: Potential for Use as Indicators of Human Fecal Contamination. Environ Sci Technol. 2005;39(14):5157-5169. doi:10.1021/ES048120K

Received: 22 June 2021

Accepted: 10 August 2021 